\title{
Unpacking the drivers behind the use of the Agricultural Innovation Systems (AIS) approach: The case of rice research and extension professionals in Sierra Leone
}

Article

Accepted Version

Creative Commons: Attribution-Noncommercial-No Derivative Works 4.0

Kamara, L. I., Dorward, P., Lalani, B. and Wauters, E. (2019) Unpacking the drivers behind the use of the Agricultural Innovation Systems (AIS) approach: The case of rice research and extension professionals in Sierra Leone. Agricultural Systems, 176. 102673. ISSN 0308521X doi: https://doi.org/10.1016/j.agsy.2019.102673 Available at https://centaur.reading.ac.uk/85916/

It is advisable to refer to the publisher's version if you intend to cite from the work. See Guidance on citing.

To link to this article DOI: http://dx.doi.org/10.1016/j.agsy.2019.102673

Publisher: Elsevier

All outputs in CentAUR are protected by Intellectual Property Rights law, including copyright law. Copyright and IPR is retained by the creators or other copyright holders. Terms and conditions for use of this material are defined in the End User Agreement. 


\section{www.reading.ac.uk/centaur}

\section{CentAUR}

Central Archive at the University of Reading

Reading's research outputs online 
Unpacking the drivers behind the use of the Agricultural Innovation Systems (AIS)

\section{approach: The case of rice research and extension professionals in Sierra Leone}

Lamin Ibrahim Kamara $^{\mathrm{a}^{*}}$, Peter Dorward ${ }^{\mathrm{a}}$, Baqir Lalani ${ }^{\mathrm{b}}$ Erwin Wauters $^{\mathrm{c}}$

a* Corresponding author: School of Agriculture, Policy and Development, University of Reading, Whiteknights, PO Box 237, Reading, RG6 6AR, United Kingdom, klamin2007@gmail.com

a School of Agriculture, Policy and Development, University of Reading, Whiteknights, PO Box 237, Reading, RG6 6AR, United Kingdom, p.t.dorward@reading.ac.uk

b Natural Resources Institute, University of Greenwich, Medway Campus, Central Avenue, Chatham Maritime, Kent ME4 4TB, United Kingdom, B.Lalani@greeniwch.ac.uk

c Institute for Agricultural and Fisheries Research (ILVO), Social Sciences Unit, Merelbeke,

Burg. van Gansberghelaan 115 bus 2, 9820 Merelbeke, Belgium; AND University of

Antwerp, Department of Veterinary Sciences, Wilrijk, Belgium,

Erwin.Wauters@ilvo.vlaanderen.be

\section{Highlights}

- Key cognitive drivers behind the use of AIS are ease of application, enhancing food security/benefits for farmers including improving their ability to innovate.

- Participants that are younger in age, female and affiliated with a specific organisation/network are more likely to use AIS.

- Social pressure from key social referents such as colleagues, employers and supervisors can positively influence the use of AIS.

- Potential barriers to using AIS are perceptions of a lack of knowledge/skills, adequate finance and incentives. 
Abstract:

Agriculture Innovation System (AIS) thinking and approaches are largely perceived as a sine-qua-non for the design and implementation of effective and sustainable agriculture development programmes. AIS has gained popularity in the agriculture innovation literature and has been embedded in policy documents of agriculture sector institutions in many countries. However, there is much less evidence of AIS thinking influencing the behaviours of research and extension institutions and staff 'on the ground'. An important research gap is the need to better understand the attitudes and beliefs of extension and research professionals regarding AIS and that drive behaviours. Sierra Leone, like most developing countries, has embraced the use of AIS (at least in theory) as evident in policy documents of government institutions - the leading innovation system actors in the country. This study uses the Theory of Planned Behaviour (TPB) to assess the cognitive foundation of agricultural research scientists and extension professionals' intention to use the AIS approach related to rice innovation (the country's staple food crop). Results show there are significant differences in intention which relate to organisation affiliation, age, and gender. Moreover, those with a high intention to use the AIS approach have significantly stronger beliefs associated with the benefits of AIS including its ease of use and the positive effects it is likely to have on smallholder farmers' food security and ability to innovate. Those with a high intention to use the AIS approach also perceive stronger social pressure from key social referents such as colleagues, employers and supervisors; suggesting that policies and an organisation's vision have a significant bearing. Furthermore, the findings suggest that impediments to the use of AIS relate to lack of finance and knowledge. Unpacking these beliefs allows possible entry points to be identified which can enhance the functioning of existing AISs and newly formed ones. The findings and framework presented are useful for many developing countries where AIS approaches are being tested.

Keywords: Agricultural Innovation Systems; Rice; Theory of Planned Behaviour

\section{Introduction}

The development of agriculture is to a large extent a function of the level of improvement in agricultural productivity of smallholder farmers, which in turn depends largely on farmers' ability and willingness to innovate. Agricultural research and extension has been the most 
useful tool in stimulating farmers' ability to innovate and thereby contributing to addressing the challenge of low productivity (Swanson et al., 1997). Agricultural research and extension services engage farmers to ensure that they have access to improved and proven technologies and that their concerns and needs are properly addressed (Mgalama, 2014). Bagchee (1994) indicates that agricultural research and extension contributes to improving the welfare of farmers and other people living in rural areas. Mgalama, (2014) mentioned that extension advisory services and programs aim to strengthen the capacity of farmers to innovate by providing access to knowledge and information.

However, the approach used in the design and delivery of agricultural research and extension services influences the effectiveness of these services in stimulating the innovative capacity of smallholder farmers. The recognition of the importance of these approaches has been evident in the past few decades, and is reflected in theories guiding the design and delivery of agricultural research and extension services. One of the earliest was the traditional 'Adoption and Diffusion Theory' advanced by Rogers $(1962,1993)$ where the course of agricultural knowledge and information is viewed as a hierarchic flow (or 'Transfer of Technology') where innovations come from the scientists to be diffused to farmers through extension services (Mulhall and Garforth, 2000; Gervacio, 2012). The change agent or extension professional is basically perceived as a "messenger" whose function is to transfer and disseminate the readymade knowledge from research scientists to farmers. This approach has been criticized due to its failure to recognize the roles of different actors in the generation, dissemination and use of knowledge and information in agriculture. There are gaps and missing links associated with the research-extension-farmer system, in which universities and research institutes innovate in isolation with dysfunctional coordination among the actors and poor linkage to the productive sector (Gervacio, 2012). With the transfer of technology approach, farmers' innovations have not been included in the knowledge system (Agwu et al., 2008). Hence, there has been an increasing emphasis on a shift to participatory approaches from the 1970s (Farming Systems Research) to the 2000s (Agricultural Innovation System).

Farming Systems Research (FSR), which emerged in the 1970s and 1980s in response to limitations of research being conducted in isolated subject areas (crops, livestock, mechanisation etc) and of the linear, top-down technology transfer approach, was also associated with a number of weaknesses including the lack of focus on farmers, poor dialogue 
between researchers and farmers, and difficulties associated with the coordination of multidisciplinary teams (Chambers and Jiggins, 1987). Following FSR was the Agricultural Knowledge and Information System (AKIS) which emerged in the 1990s (Klerks et al., 2012). AKIS has also been criticised for a number of weaknesses including seeing the agricultural research system as the centre of innovation, limited ability to analyse systems beyond the sphere of the public sector and a limited perspective of the heterogeneity among agents, the institutional context that conditions their behaviours and the learning processes that determine their capacity to change (Gervacio, 2012). The shortcomings of the preceding approaches led to the emergence of the Agricultural Innovation Systems (AIS) in the 2000s as an approach for enhancing the effectiveness of agricultural research and extension services design and delivery (Leeuwis, 2004; Klerkx et al., 2012). It focuses on obtaining a better understanding of the innovation processes and looking at them as multidimensional and complex interactions, and consisting of novel and interdependent practices implemented by diverse actors (Gervacio, 2012). AIS is perceived to have a greater and more explicit focus on: 1 . The influence of institutions, which are seen as organisations like companies, public research institutes and governmental entities but also regulations and standards (hard institutions) and norms, informal rules and habits (soft institutions) and infrastructures on learning and innovation and; 2 . The inclusion of all relevant organizations beyond agricultural research and extension systems (Klerkx et al., 2012). The AIS perspective is thus considered as a more holistic approach that promotes the participation of a range of actors outside the agriculture environment including the institutions and policies that influence their behaviours in agricultural innovation processes (Leeuwis, 2004).

However, despite this transition (in theory) from top-down transfer of technology approaches to the Agricultural Innovation System approach, Roling (2006) maintained that technology transfer continues to dominate innovations in Sub-Saharan Africa and the design and operation of research and extension services. Klerkx et al., (2012) similarly noted that despite the emergent AIS thinking, there is still adherence to transfer of technology thinking and practice as well as farming system thinking disconnected from the broader systemic views on innovation. This suggests that despite the perceived benefits of the AIS approach in increasing the effectiveness of agricultural innovation programs, there is still a limitation in its utility by practitioners in the design and implementation of research and extension programs. 
This study is therefore motivated by the body of literature on AIS which suggests that even though the AIS approach is perceived as the most appropriate for the design and implementation of sustainable and effective research and extension programmes, there seems to be an adherence to linear, top-down approaches in the developing world.. In Sierra Leone, policy documents of the leading and regulatory national institutions on agricultural research and extension [the Ministry of Agriculture, Forestry and Food Security (MAFFS) and Sierra Leone Agriculture Research Institute (SLARI)] theoretically support the adoption of an AIS approach in agricultural innovation processes (MAFFS, 2012; SLARI, 2011). However, the current (though limited) literature on agricultural research and extension suggests the contrary. This study makes a contribution to the existing literature by researching the drivers for the use of AIS approach by research and extension professionals in the country. It assesses key beliefs and perceptions regarding the use of AIS, framed in a more holistic behavioural framework (theory of planned behaviour). Section 2 presents the behavioural framework used, followed by the methodology and the third section presents results. Section 4 provides the discussion and conclusion.

\section{Background}

\subsection{Study Area}

Sierra Leone is on the west coast of Africa between $6^{\circ} 55^{\prime} \mathrm{N}$ and $10^{\circ} 00^{\prime} \mathrm{N}$. It is bordered on the North and North-East by the Republic of Guinea, and on the East and South-East by the Republic of Liberia. The Atlantic Ocean extends approximately $340 \mathrm{~km}$ on the West and SouthWest. The country covers a total land area of $72,325 \mathrm{~km}^{2}$, of which, almost $75 \%$ is arable (MAF, 2004; MAFFS, 2011). Upland and lowland ecologies make up 78\% and 22\% respectively of the arable land area. The uplands are composed of forest, savannah woodlands and grasslands while the lowlands comprise 690,000 hectares (ha.) of inland valley swamps, 145000 hectares of 'bolilands' (or large, saucer-shaped basins), 130,000 hectares of riverine grasslands; and 200,000 hectares of mangrove swamps (MAF, 2004; Bangura, 2006).It is a relatively small country compared to other African countries with a total population of 7,092,113, of whom 51\% live in rural areas (Sierra Leone Population and Housing Census, 2015). 
Despite the abundant natural and human resources, poverty is still a widespread problem with an estimated $57 \%$ of the population living below the international poverty line of $\$ 1.25$ a day, $70 \%$ below the national poverty of US\$2 a day, and $26 \%$ live in extreme poverty. The country is among the 10 poorest countries in Sub-Saharan Africa (World Bank, 2013). The 2011 Human Development Index ranked the country 180 out of 187 countries. In 2012, the International Food Policy Research Institute ranked Sierra Leone among the nine least-improved countries with the highest global hunger index score (24.7), and the hunger situation being classified as "alarming" in the country. About $45 \%$ of the population is estimated to be food insecure (WFP, 2011) as measured by the food consumption score $^{1}-$ a clear manifestation of the level of food insecurity in the country.

Agriculture is the backbone of Sierra Leone's economy, accounting for about 46 percent of the country's GDP and employing about 75 percent of the population (MAFFS, 2011; RSL, 2009). Being an Agrarian economy, agriculture is the main source of livelihood for over $75 \%$ of the total population of the country (Conteh, 2003; MAFFS, 2004; Bangura, 2006).

The main staple food in Sierra Leone is rice and is cultivated by all small-scale farmers with a total annual per capita consumption of 104kg (MAF, 2000; Bangura, 2006). The contribution of rice to caloric intake in Sierra Leone is ranked the highest in Sub-Saharan Africa (MAF, 2004).

The cultivation of rice in the country suffered serious drawbacks particularly during the civil strife in the 1990s, which severely contributed to a persistent declining trend in the overall rice production system in the country, leading to a huge rice importation (Bangura, 2006; WARC, 2013). However, the end of the war in 2002 brought about some progress in the agriculture sector including increases in rice productivity as well as other crops. Government institutions were revitalised, and there was increased funding from diverse multilateral agencies such as the World Bank, FAO, EU etc for the development of the agriculture sector through the Ministry of Agriculture, Forestry and Food Security. Many Non-Governmental Organisations emerged with key priorities in developing the agriculture sector (MAF, 2004; MAFFS, 2011) due to its role in the overall development of the country. The greater prioritization of the agriculture sector correspondingly led to an increase in the number of actors providing research and extension services, mostly geared towards augmenting the productivity of major crops

${ }^{1}$ The Food Consumption Score is a measure of the amount of food eaten by a household over a given period of time taking into account its relative nutritional value. 
including rice among smallholder farmers in the country. However, the extent to which the diverse actors in the sector have adopted an AIS approach in the design and delivery of research and extension programmes remains unclear..

\subsection{Agricultural Research and Extension in Sierra Leone}

The earliest research and extension efforts in Sierra Leone date back to the colonial era during which agricultural policies were geared towards the production and supply of tropical crops to the countries of the colonial masters. The subsequent and gradual change in priorities and policies of the agriculture sector led to the establishment of various departments/units geared towards development and dissemination of agricultural technologies nationwide. For example, the Botanical Garden in Freetown, the Njala Experimental Station, the Department of Agricultural Extension and the Rice Search Station at Rokupr were established to address the extension needs for different crops and regions.

Up to 1961 research and extension activities were planned and managed at the headquarters of the Department of Agriculture based at Njala, Southern Sierra Leone. However, a number of constraints that limited the effectiveness of the colonial research and extension system as highlighted by the Ministry of Agriculture, Forestry and Food Security (MAFFS, 2012) include: paying little attention to local food crops such as rice, cassava, potatoes, yams, maize, beans and livestock associated extension delivery services; grass-roots extension staff were poorly incentivized; support services and infrastructure were inadequate to enhance effective communication; and supervision, control and monitoring were weak.

The National Agricultural Research Coordinating Council (NARCC) was established in 1985 to coordinate research and harmonize research activities (SLARI, 2011). The mission of NARCC was to support the promotion of pro-poor sustainable growth for food security and job creation as part of Sierra Leone's Poverty Reduction Strategy Paper. The two constituent institutes of NARCC were the Rice Research Institute dealing with rice, millet, sorghum, banana, plantain and vegetables, and the Institute of Agricultural Research dealing with cassava, sweet potato, yam, maize, cowpea, groundnut, soybean and sesame (ibid). Njala University and the University of Sierra Leone also carried out agricultural research in addition to these institutes.

The Sierra Leone Agriculture Research Institute (SLARI) was established in 2007 to replace NARCC and serve as the technical arm of the Ministry of Agriculture, Forestry and Food 
Security (MAFFS). With seven research centres in different parts of the country, it conducts research to obtain knowledge, information and technologies needed for sustainable development of the country's agriculture sector (SLARI, 2011). Agricultural research is also conducted in Universities particularly Njala University in Southern Sierra Leone. The country further benefits from the participation of international research institutions such as IITA, and some private sector institutions including NGOs. However, public institutions, namely SLARI and the Ministry of Agriculture, have been the key providers and regulators of research and extension services.

Research and extension services before, and for a reasonable period of time after the postcolonial era (from the 1960 s to early 70 s), were mainly provided using the Transfer of Technology model (MAF, 2004). This was based on the widely held belief that scientists in such institutions best know the needs of farmers. There was also limited private sector participation in the provision of research and extension services during this period (ibid). Subsequently, there was a shift in perspective (at least in theory) from top-down approaches to more participatory approaches due to the recognition of the shortcomings of the TOT model. The country's agricultural policies including the National Agricultural Extension Advisory Policy and the Strategic Plan 2012-2021 of the Ministry of Agriculture, Forestry and Food Security and SLARI respectively, currently support the adoption of the agricultural innovation systems approach, borne out of the recognition of the importance of the contributions of the other players outside government research and extension (such as NGOs and the private sector), and the increasing relevance of farmers' participation in the development, planning and implementation of agricultural innovation programmes (GoSL, 2010).

The Sierra Leone Agriculture Research Institute (SLARI), MAFFS, NGOs and the private sector have been promoting rice innovations among smallholder farmers in varying contexts, scales and capacities (MAFFS, 2009). However, despite the many actors in the agriculture sector providing research and extension services to smallholder rice farmers in the country, the sector still lags behind in meeting the national food requirement of the population as productivity remains low (RSL, 2009). An estimated one-quarter of rice consumed in the country is imported, and households spend approximately 50\% of their incomes on food (WARC, 2013). SLARI (2011) indicated that the low productivity is attributed among other factors to the inappropriate production practices by farmers due to lack of awareness or low adoption of improved technologies and lack of access to credit. The poor quality and high cost 
of inputs and inappropriate policies on cereal investment as well as the lack of suitable varieties with desirable traits and established seed systems to service the sector, have been key constraints.

On the other hand, limited (if any) knowledge exists on the extent to which research and extension professionals have effected an AIS approach in their activities and their level of motivation in doing so or not.

This therefore justifies the need to critically examine research and extension professionals' perceptions of the use of AIS approach in program design and delivery, their attitudes and beliefs regarding AIS, their intention to use it, and key barriers and drivers influencing this. We will also explore whether the apparent limited functioning of the rice AIS is partly evident of a weak motivation to use AIS approach by research and extension professionals.

\subsection{The Agricultural Innovation System in Sierra Leone}

The Agriculture Innovation System (AIS) in Sierra Leone is comprised of multiple actors, both in the public and private sectors. As shown in figure 1, the system comprises three main domains: Farmer Enterprises, Intermediaries/Bridging Institutions and Research \& Education Institutions. These domains contain the key actors in the AIS that are interacting in some way to facilitate the development and access to agricultural innovations. Their interactions are however influenced by the support structures, policy processes and the demand structures (MAFFS, 2012).

The Farmer Enterprises domain constitutes mainly farmers and farmer groups, who normally operate at community level and are generally the ultimate beneficiaries of 'external' innovations. Intermediaries, such as NGOs, the Ministry of Agriculture and private sector actors and the research and education actors such as SLARI and Njala University are the key actors involved in the development, testing and dissemination of 'external' innovations on rice and other crops. While linkages between a few actors and structures are perceived to be strong (see figure 1), the vast majority of linkages between actors in the AIS in Sierra Leone are seen to be weak, and in some cases gaps exist denoting the almost non-existent of linkages between actors. Key actors continue to innovate from a top-down, transfer of technology approach. Smallholders still lack support in accessing the services provided by the private sector such as financial, processing and transportation services as evident by the gaps between farmer enterprise and support structures. The existence of these gaps and weak linkages among the 
majority of innovation actors and support structures has translated into a generally weak innovation system in Sierra Leone. Research and extension professionals largely operate in 'silos' with little participation of private sector actors in their innovation processes, and viceversa. There is currently little or no application of AIS approaches especially in leading innovation system organisations such as SLARI and the MAFFS. For instance, the GOSL (2009) highlighted that SLARI, the technical arm of the MAFFS continues to operate in a conventional research-driven model as it has limited capacity at present to work in a more interactive farm-based model, which would reflect an effective AIS. AIS approaches such as the use of innovation platforms has been tried by SLARI but has so far been perceived to be unsuccessful. Understanding the underlying beliefs for research and extension professionals' use of an AIS approach in innovation processes in the country therefore becomes relevant and necessary.

Figure 1: Analysis of Sierra Leone Agriculture Innovation System

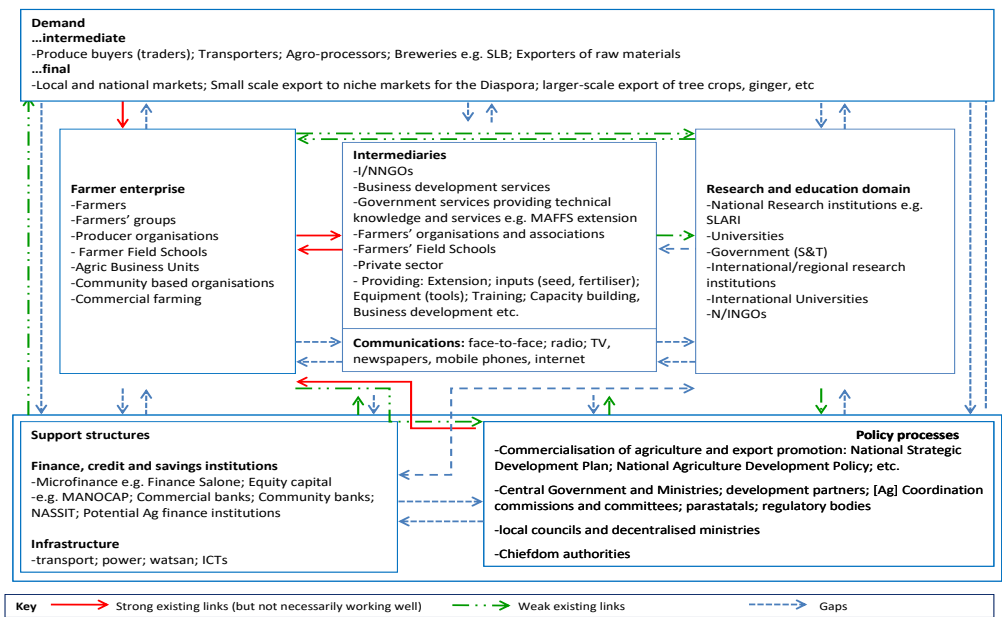

Source: Ministry of Agriculture, Forestry and Food Security (2012)

\subsection{Use of AIS Framework}

The AIS approach has become increasingly popular as a framework to analyse and explore solutions to complex agricultural problems (Schut et al., 2014). Spielman and Birner (2008) identified the indicators that can be used to measure innovation inputs, processes, and outcomes using an AIS framework. This framework, which they adapted originally from Arnold and Bell (2002) consists of three essential elements, which include: (a) a knowledge and education 
domain; (b) a business and enterprise domain; and (c) bridging institutions which link the two domains. In addition to these elements, this framework also makes reference to conditions that support or impede innovation, including: public policies on innovation and agriculture; informal institutions that establish the rules, norms, and cultural attributes of a society; and the behaviours, practices, and attitudes that condition the ways in which individuals and organisations within each domain act and interact. Further, the framework emphasises linkages beyond the borders of the system, such as those which involve international actors, and other sectors of the economy.

Temel et al., (2002) assessed institutional linkages in Azerbaijan from an innovation system framework. Their study assessed the AIS in the country by characterising the patterns of innovation activities of different organisations, the patterns of interactions between them, and factors which constrain their interactions. The study considered policymakers, research and education institutions, extension and information units, farming organisations, and external assistance organisations as the main actors in the innovation system and examined the linkages between and among them. The scope of this study was narrowed to focus only on the interactions and links between actors in the innovation system. Other aspects of the system, such as the support system, were not examined. Mambo (2014) also adapted the AIS framework and perceived it to constitute linkages among four key actors: markets, researchers, farmers, and extensionists, influenced by their economic, social, cultural, political, and institutional environments, to determine agricultural innovation and, hence, the impact on smallholder farmers' livelihoods. While this provides a basis that could be useful to analyse innovation, it does not consider the practices and behaviours of actors which could enhance or constrain innovation.

\subsection{Limitations of the AIS Approach}

Despite the perceived usefulness of the AIS approach in increasing the effectiveness of agricultural innovation processes, it is viewed by some to have a number of limitations or challenges which can thwart its utility and/or effectiveness. One of the key weaknesses of the AIS perspective, as indicated by Klerkx et al., (2012) is the assumption that all actors have a common goal related to the enhancement of innovation. Little recognition has been given to 
the fact that interdependent actors may have different interests, goals, and perspectives which are likely to diverge and conflict within the system. This needs to be taken into account when assessing participation, and the roles and behaviours of certain actors in the innovation process. Further, although the innovation system concept promotes the collaboration and interaction of different actors, Hall (2007) observed that there lies a challenge in the selection of who to work with as the selection of too few actors will miss the point of the innovation system concept, while too many may become unmanageable. It can be deduced from this that, although it is important to engage diverse actors in the innovation process, there is a need to consider the role that each actor may play, and whether their participation may influence the desired results.

\section{Materials and Methods}

\subsection{Theoretical framework}

The Theory of Planned Behaviour (TPB) is a socio-psychological model which was developed by psychologists for understanding and predicting human behaviour (Ajzen, 1991; McKemey\&Sakyi-Dawson, 2000). The TPB was preceded by the Theory of Reasoned Action (TORA) which was first put forwarded by Fishbein in 1967 and developed further in the early 1980s by Azjen and Fishbein to form the TPB model. The TORA was extensively used in many studies to link attitudes and behaviours, and a considerable body of empirical evidence has led to its explanatory and predictive powers becoming widely recognized (McKemey and Rehman, 2005). It is one of the "expectancy-value" models of human behaviour and its terminology according to Lynne (1995) is not very different from that of the well-established subjective expected utility model used by economists. It assumes that human beings can behave in a sensible manner, meaning, they can take account of available information and implicitly consider the implications of those actions (Ajzen, 1988).

The TORA explores an individual's strength of intention to perform an action i.e. behaviour, and the contribution of factors influencing it. These are the individual's 'attitude' to the behaviour under evaluation and 'subjective norms'. Attitudes are primarily determined by the beliefs about the outcomes of performing the behaviour and the evaluation of these expected outcomes. On the other hand, the subjective norm is dependent on beliefs about how others feel the individual should behave, and the individual's motivation to comply with these 'important others' (Ajzen \& Fishbein, 1980). In the TPB, it was recognized that even when 
attitudes and subjective norms are positive towards the behaviour, people do not always proceed to execute the behaviour, because of a lack of ability and control, e.g., due to the absence of necessary prerequisites such as time, skills and budget. Hence, in the TPB, the concept of perceived behavioural control was added, which results from control beliefs, i.e. beliefs about how important certain preconditions are for their ability to perform the behaviour, and whether these preconditions are present.

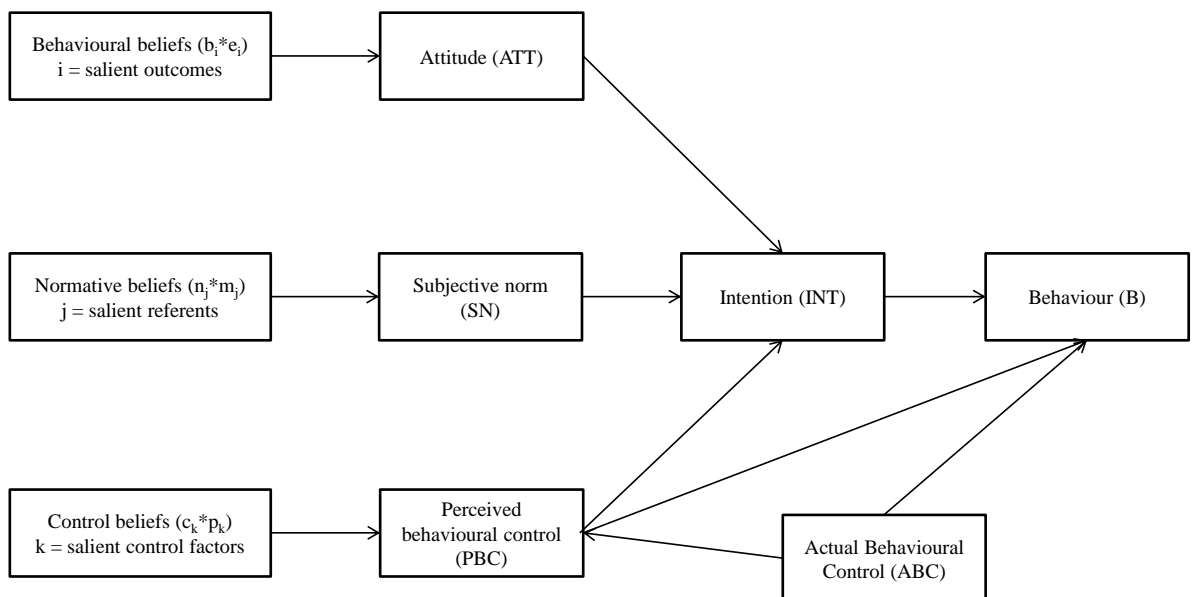

Figure 2. Theory of planned behaviour (Adapted from Azjen, 1991)

Behavioural, normative and control beliefs are the fundamental determinants of one's attitudes, subjective norms and perceived behavioural control respectively, towards the performance of a behaviour. These beliefs play an important cognitive role in determining the sociopsychological constructs. Fishbein and Ajzen, (1975) indicate that belief based measures are calculated using the expectancy-value model. The behavioural belief $(b)$ is multiplied by the outcome evaluations of those beliefs $(e)$, and these are then aggregated to determine the overall attitude weight. Consistently, subjective norms are calculated by multiplying normative beliefs i.e. expectations of others $(n)$ by the motivation to comply with their opinions $(m)$, and the results are then aggregated to determine the overall subjective norm. The perceived behavioural control is determined by multiplying the control beliefs $(c)$ by the perceived power of control ( $p$ ) that either inhibit or help to facilitate the behaviour. The results are summed up to form an overall weight for the perceived behavioural control (Wauters et al., 2010; Borges et al., 2014; 
Lalani et al., 2016). The following equations below show the relationship between the beliefs and their respective constructs:

$A=\sum_{i=1}^{x} b_{i} e_{i}$

$S N=\sum_{j=1}^{y} n_{j} m_{j}$

$P B C=\sum_{k=1}^{z} c_{k} p_{k}$

A similar notation is used to that of Lalani et al., (2016), Wauters et al.,(2010) and Borges et al., (2014) where $i$ is the $i$ th behavioural belief, $x$ the total number of behavioural beliefs, $j$ the $j$ th referent, $y$ the total number of referents, $k$ the $k$ th control factor and $z$ the total number of possible control factors. It is worth noting that we did not quantitatively calculate attitude, subjective norm and perceived behavioural control using the expectancy-value theory, however, it provides us the framework for investigating the drivers (beliefs) that determine attitude, subjective norm and perceived behavioural control in relation to the use of the AIS approach by research and extension professionals.

\subsection{Survey procedure}

The study adopts a sequential mixed-method research approach, in which qualitative data collection preceded the quantitative data collection stage. Sequential mixed-methods have been widely used in agricultural research to shed light on often complex phenomena, such as farmers' and research and extension professionals' behaviour (e.g. Arriagada et al., 2009, Mose, 2013). The results of the first stage (qualitative stage) were used to design the data collection instrument used in the second stage (quantitative stage). According to the TPB conceptual framework, outlined above, key themes exploring the advantages and disadvantages of the behaviour, in this case, "use of AIS approach" were explored. Moreover, these interviews were used to elicit information on social norms and social referents and existing control factors affecting adoption of the AIS approach. Knowledge of these elements is necessary to construct the survey instrument intended to quantitatively assess research and extension professionals' beliefs related to the outcomes, referents and control factors relating to the use of AIS approach in the design and delivery of their services. 
Research and extension professionals from the public and private sectors were targeted for the study. Research scientists were sampled from SLARI, the umbrella agricultural research institution in the country; while extension professionals were sampled from the MAFFS and Agriculture-Sector NGOs at both stages of the study. Qualitative data was collected through Focus Group Discussions. Though opinions vary on the group size and composition of FGDs, for example Stewart and Shamdasani (1990) suggest 8 to 12, whereas Morgan (1998) opts for 6 to 10, Robson (2011) highlighted the use of convenience samples and pre-existing groups by most researchers in the conduct of FGDs. This study aligned itself with both Robson (2011) and Morgan (1998). The study used a convenient sample size of at least 4 participants for the FGDs for research and extension professionals since it was difficult getting many participants at the same time owing to their official duties/engagements. The FGDs were conducted at two levels - senior management and junior levels. This was to ensure that perspectives from the "top" and "bottom" cadres of the target organisations were fully captured so as to provide a complete picture reflecting the views of all categories of respondents. A total of 12 FGDs were conducted among research and extension professionals at the elicitation stage for generating the beliefs used in computing the TPB variables. Three FGDs were conducted with research scientists ( one with senior staff level, two with junior staff level); five FGDs with MAFFS personnel (one at national/senior staff level, and four at junior level in each district); four FGDs with NGO personnel (one at national/senior level, and three at junior level staff) in each district. During the FGDs, participants were asked to: a) Individually list the key behaviours that characterise a functioning AIS in research and extension; b) Individually list the advantages and disadvantages of using an AIS approach in research and extension programmes; c) List people or organisations that would approve or disapprove of its use; d) List conditions that would make it easy and difficult if they were to use an AIS approach in their work.

After completion of this exercise, participants shared their responses in a plenary session. The responses were listed on a flip chart and scored based on their frequencies. This was repeated in all FGDs conducted with research and extension professionals. Responses with the highest frequencies were then compiled by the researcher and they formed the basis for the elicitation stage of the TPB variables including outcome beliefs, salient referents and control beliefs. The results from the FGDs were used for the formulation of structured questionnaires used to elicit data for the TPB variables. The structured questionnaires were divided into three sections including the socio-economic characteristics of respondents, knowledge of agricultural 
innovation systems approach, and Theory of Planned Behaviour in relation to AIS. The section on the TPB model followed the process described in Ajzen (1991), Francis et al. (2004), and Rehman et al. (2007) where information elicited from the Focus Group Discussions were used.

Agriculture research scientists and extension personnel were purposively selected from the target institutions. This was to ensure that all relevant cadres of staff were included. A list of all Agriculture-sector NGOs registered with MAFFS was obtained from the NGO Desk Officer at MAFFS. NGOs implementing, or who have implemented, programmes on rice from 2005 to 2015 were identified by the researcher with assistance from the NGO Desk Officer. As a result, invitation letters were extended through the NGO Desk Officer at MAFFS whereby one senior and one junior member of staff from each organisation who have been directly involved in agriculture programmes were invited to participate in the workshops. For the quantitative survey, the questionnaires were distributed to professionals of the target organisations (MAFFS, SLARI, NGOs) by the researcher, making conscious efforts to target senior, middle, and frontline professionals in all the institutions selected. The survey initially targeted a total of 140 respondents -40 research scientists from SLARI and 100 extension professionals (50 each from MAFFS and NGOs). However, only 122 questionnaires were returned by the target respondents (87\% response rate) - 35 from research scientists (87.5\%), 42 from NGO extension professionals ( $84 \%$ response rate), and 45 from MAFFS extension professionals (90\% response rate).

\section{Figure 3. Graphical representation of survey procedure}

$\begin{gathered}\text { Data Collection } \\ \text { Method/Tool (Total } \\ \text { Number) }\end{gathered}$
Suestionnaires (122)




\subsection{Variables and measurement}

The key variables measured by the study revolve around the socio-economic characteristics of the respondents and the TPB variables i.e. Attitudes, Subjective Norms and Perceived Behavioral Control, in relation to AIS. The key socio-economic variables include age, sex, level of education, nature of work/organization, years of experience in research or extension, membership in professional networks, and other sources of income. Age and years of experience in research or extension were measured as an interval variable divided into four intervals (with codes 1-4). Sex, membership in professional networks, and other sources of income were measured as dichotomous variables, while the level of education was measured as ordinal variable. The nature of work/organization was measured as a nominal variable.

With respect to TPB, the behavior measured was the "the use of AIS approach in research and extension programmes". The behavioral intention (BI) was measured through the use of three items to assess the strength of respondents' intent to use the behavior. Respondents were asked to indicate the extent to which they agree or disagree with the statements including: 1) I expect to use (the behaviour) in the next 12 months; 2) I want to use (the behaviour) in the next 12 months; 3) I intend to use (the behaviour) in the next 12 months. The results were scored using a scale from 1-5 (1 denoting strongly disagree, and 5 strongly agree). These were then recoded after the data collection using a 5 point bi-polar scale ranging from +2 (very strong) to -2 (very weak) intention to use/exhibit the behaviour. The final score for the behavior variable was obtained by taking the simple average of the scores on each individual item.

Attitudes can be measured in two ways: the stated response (SA), and the calculated or reasoned response (CA) (Rehman et al., 2007). In this study, only the second measure is used. Respondents were asked to score their "belief strength" for each of the 13 belief statements elicited during the FGDs, using a Likert-type scale ranging from 1 to 5 (where 1 represents strongly disagree and 5 strongly agree). These were recoded into a 5 point bipolar Likert-type scale ranging from -2 (strongly disagree) to +2 (strongly agree). Respondents were also asked to evaluate each outcome belief statement on a 5 point bipolar Likert-type scale ranging from -2 to +2 (where -2 represents extremely bad and +2 extremely good). The resulting belief strengths and their corresponding evaluation by respondents were then used to analyze the variances between low and high intenders.

Subjective norms (SN) that form part of the main TPB constructs, measures how the 'important others' (who may be individuals or organizations) influence the respondents' behaviour. There 
are two measures that have been proposed for this construct; the direct and indirect measures. In this study, the indirect measure is used. The indirect subjective norm was determined by asking respondents to rate how strongly each of the identified individuals or groups of individuals (employer, professional colleagues, donors, farmers, community leaders, and family members) would likely want them to adopt the use of the AIS approach in research or extension over the next 12 months. They were asked to score their responses on a 5 point Likerttype scale ranging from 1 to 5 (where 1 represents very unlikely and 5 very likely). These were also re-coded during the analysis ranging from -2 to +2 (where -2 represents very unlikely and +2 very likely). To determine their motivation to comply with these referents, respondents were asked to rate how motivated they are in complying with each of the referents. Their responses were initially recorded using a 5 point Likert-type item ranging from 1 to 5 (where 1 represents very weak and 5 very strong) and then re-coded into a 5 point bipolar Likert-type item ranging from -2 to +2 . These were then used to analyze variances that exist between low and high intenders to use an AIS approach in research and extension.

The Perceived Behavioural Control (PBC) was also indirectly measured using the six control belief items elicited during the FGDs. Respondents were asked to rate how strongly they agree or disagree with each of the statements using a 5 point Likert-type item ranging from 1 to 5 (where 1 represents strongly disagree and 5 strongly agree). These were re-coded into a 5 point bipolar Likert-type item ranging from -2 to +2 during the analysis. Similarly, respondents were also asked to evaluate the power of control of each control belief. These were then coded and re-coded as described above. These were then used to analyze the variances that exist among the variables examined in this study.

Figure 4. TPB variables/Indicators used in the analysis 


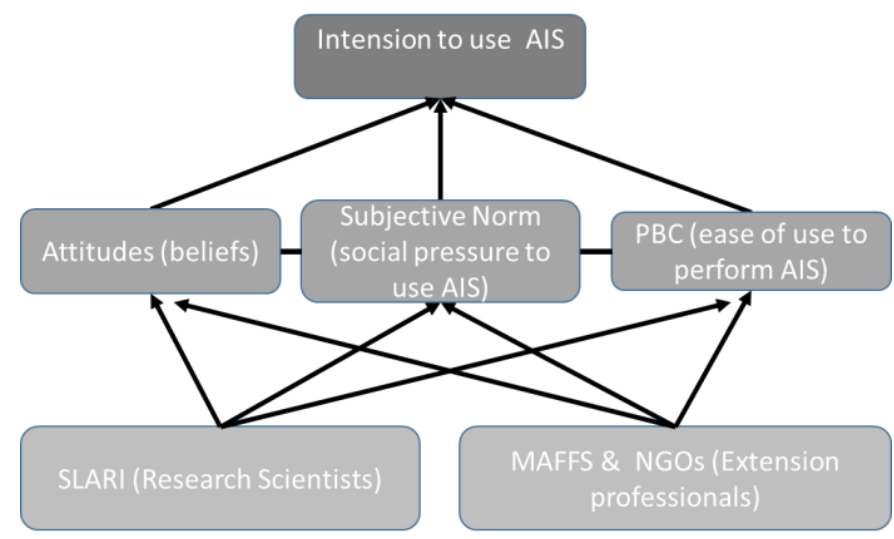

\subsection{Data analysis}

Qualitative data generated during the study was analysed using the following approaches including: 1) transcribing of field notes; 2) coding and categorisation (using different colours) $\&$ condensation into various themes; and 3) interpretation of meaning using Microsoft Word. These techniques were used in organising texts emerging from the FGDs for making implicit meaning of what was said by respondents for each objective. As noted by Miriam (1988), qualitative data analysis is best done in conjunction with data collection, suggesting that the researcher should organize the information gathered immediately after the interview. A similar strategy was followed by the researcher during the qualitative data collection, and this helped the researcher to adequately record all relevant information emerging from the interviews. The quantitative data was analysed in SPSS version 24.0. First, the data was cleaned by checking for cases with too many missing values, outliers and irregularities. We dichotomized intention into a new variable, high intention, being 1 when intention was higher than 0 , on a scale from -2 (very negative intention) to 2 (very positive intention) and 0 otherwise (low intention). We compared mean scores of the TPB between a number of variables that have been hypothesized to influence usage of AIS; these being education level, membership of professional networks, age, etc. We performed a series of mean comparison analyses to compare the mean level of the indirect beliefs (associated with the broader theory of planned behaviour) between those with a high intention and low intention and for different organisations, using analysis of variance (ANOVA). When there were more than two groups, we performed post-hoc tests, which were 
evaluated using Tukey HSD in case of equal variances and Dunnett's T3 in case of unequal variances. The equality of variance assumption was evaluated using the Levene's test.

\section{Results}

\subsection{Summary statistics}

Table A1 (in appendix A) shows the summary statistics of the sample. The majority of respondents $(86.1 \%)$ are male, and only a few (13.9\%) are female. This suggests very low employment of female staff in the agricultural research and extension sector. This disparity may stem from the traditional belief among the vast majority of Sierra Leoneans that the study of agriculture is mainly for men, and therefore very few females tend to pursue agriculture as a course of study at higher education institutions. Though the overall number of female respondents was small, however, the Ministry of Agriculture, Forestry and Food Security (MAFFS) seems to be recruiting more female staff than NGOs or SLARI. This is possibly due to the higher qualifications required in the recruitment criteria in the latter institutions. For example, SLARI are widely known for recruiting at least graduates with division two or better, hence, barring less qualified graduates from applying. NGOs are known to use similar recruitment criteria.

The majority of respondents fall within the age brackets of 31-40 years and above. While a higher number of respondents (37.7\%) are between 31-40 years, a striking number of them (25.4\%) are 50 years and above old. The latter are mainly found in NGOs and SLARI. This is possibly due to the fact that most staff within NGOs are recruited based on their experience with little consideration to their age. The more experienced you are, the more likely you are to be recruited in an NGO. Similarly, SLARI is also known for retaining highly skilled staff that are considered as "specialists" in certain areas. The MAFFS on the other hand, has undergone a recent (2016) retirement and redundancy process for staff up to 60 years and over and focused on recruitment of younger professionals. This largely explains the low number of older respondents from the MAFFS compared to SLARI and NGOs.

Further, more respondents hold at least a Bachelor's degree (48.1\%) or higher. However, more respondents within SLARI (42.9\%) hold a Master's degree compared to those from MAFFS $(11.1 \%)$ and NGOs (19.0\%). This is possibly due to the fact that SLARI requires staff to undertake postgraduate degrees in the first two years of employment before they can be 
confirmed as research scientists (SLARI, 2011). However, only a few respondents (2.5\%) hold a $\mathrm{PhD}$ and $1.6 \%$ are from SLARI, $0.8 \%$ from MAFFS, and none from NGOs. The majority of respondents $(61.5 \%)$ depend on their job for their only source of income, while only $38.5 \%$ indicated they have additional sources of income. Most respondents from NGOs (59.5\%) had other sources of income, followed by MAFFS (31.1\%), and then SLARI (22.9\%). It is believed that this has either a positive or negative impact on the performance of staff, depending on the situation. For instance, having another source of income may serve as security in the event of job loss, e.g., NGO professionals, who are normally hired on a contractual basis, may not have their contract renewed. On the other hand, it may lead to a divergence of focus and in cases where the second source of income seems more profitable, research and extension responsibilities may be compromised.

Respondents' participation in inter-agency meetings was also measured as these could serve as a platform for sharing ideas and experiences on agricultural innovation processes and similar topics among research and extension actors. The majority of respondents $(76.2 \%)$ indicated they had participated in inter-agency meetings in the past 12 months. Interestingly, all respondents from NGOs indicated they had done so. On the contrary, just over half of respondents within SLARI (51.4\%) indicated they had not attended such meetings, and neither had $80.0 \%$ of respondents within MAFFS. The high attendance of NGOs is possibly due to their drive for collaboration, and sometimes as a result of the need to report their activities to other agencies, such as MAFFS and SLANGO. The low-participation reported byf respondents from SLARI suggests weak interaction of SLARI with other actors within the agriculture sector. Similarly, more respondents within NGOs (73.8\%) indicated they are members of professional networks, compared to only $22.2 \%$ from MAFFS and $22.9 \%$ from SLARI. Surprisingly, more than half of all respondents (59.8\%) do not belong to any professional networks. This suggests that most respondents may find it difficult to keep up-to-date with current practices and principles in their respective fields due to their limited networking with colleagues of similar backgrounds in other agencies. The majority of respondents $(82.0 \%)$ indicated they had attended training sessions related to their jobs in the last 12 months. More respondents within NGOs $(95.2 \%)$ indicated they have done so compared to those within SLARI (60.0\%) and MAFFS (86.7\%). This suggests that there is a high-level drive to upgrade staff skills and knowledge in their various roles, particularly in NGOs and MAFFS. With regards to experience in research and extension, the majority of respondents $(63.9 \%)$ had 
experience ranging from one to 10 years, while $20.5 \%$ had experience ranging from 11-20 years. Only a few (6.6\% and 9.0\%) had experience ranging from 21-30 years and 31-40 years, respectively. The mean number of years of experience was 11.1. This largely suggests that respondents have had a reasonable amount of experience in research and extension activities, enough to coordinate successful innovation programmes in their respective organisations. Similarly, the majority of respondents $(77.9 \%)$ had only served in their respective organisations for one to 10 years, and the remainder between 11-20 years, or longer. The mean years of service was 8.64. Unsurprisingly, none of the respondents from NGOs indicated they had served in their organisations for more than 10 years. This is possibly due to the contractual nature of jobs in NGOs, with contracts usually lasting between three and five years, and only extended upon availability of funding for the project and the necessity for the position.

Research and extension professionals' backgrounds in agriculture were measured based on the belief that this may influence the way they perceive farmers' problems, and possibly the way they engage with them. The vast majority of respondents $(92.6 \%)$ indicated they have a background in farming, i.e., they have participated in farming themselves, either as a child or an adult. This might have served as one of the motivating factors for them to pursue agriculture as a course of study. All respondents from NGOs (100\%) indicated they had a farming background compared to their MAFFS (82.2\%) and SLARI (97.1\%) counterparts. Further, research and extension professionals' ability to speak the lingua franca of their areas of operation is considered important as this may impact on their interaction and engagement with community stakeholders, and the effectiveness of the communication process. In this regard, more than half of respondents $(75.4 \%)$ could speak the local language in their areas of operation, with the majority of respondents within NGOs (90.5\%) able to do so, compared to $68.9 \%$ from MAFFS and $65.7 \%$ from SLARI. This largely suggests that NGOs may be better at engaging community stakeholders with little distortion to communication since the majority of them can speak directly with programme participants without the aid of an interpreter.

Table A2 (in Appendix A) shows comparisons for the mean intention to use AIS and various socio-economic characteristics. The results show that female professionals have a significantly stronger mean intention to use an AIS approach than their male counterparts $(\mathrm{P}<0.05)$.

This may suggest that women professionals are more likely to try new ways of doing things than their male counterparts which has also been found in other spheres. In addition, the mean stated intention for younger professionals between 18-30 years is significantly stronger than 
their older counterparts from $41-50$ years $(\mathrm{P}=<0.10)$ and above 50 years old $(\mathrm{P}=0.001)$. These results also show that intention of respondents decreases with age. Interestingly, there is a difference in intention evident with the organisations that the respondents are affiliated with. Respondents from the MAFFS have a significantly stronger mean intention than SLARI $(\mathrm{P}<0.05)$. The possible reason for this disparity due to MAFFS's greater focus on extension activities compared to SLARI. MAFFS may possibly perceive their activities to be more interactive and require the involvement of diverse actors than their counterparts at SLARI do. A similar result is also observed regarding respondents' membership in professional networks. Members have a stronger mean intention than non-members $(\mathrm{P}<0.05)$. The higher mean intentions of inter-agency meeting participants and members of professional networks could indicate that they have been learning things related to AIS approach and are therefore more informed about the relevance of the approach in enhancing the effectiveness of innovation processes particularly with smallholder farmers. It may also indicate a predisposition to cooperation and interaction with other individuals and organisations. It is also interesting to note that no significant difference was found between respondents who have a background in farming and those that do not. Surprisingly, however, the results do show that there is a negative association between education and intention to use AIS. Respondents with a Bachelor's degree have a significantly stronger mean intention to use an AIS approach than respondents with any other qualifications including those with higher qualifications (eg Masters). This may be partly explained by the fact that Bachelor's graduates are more open to new ideas as most of them may not have been closely involved in work using traditional top-down approaches in research and extension programmes. The following section unpacks the beliefs associated with the intention to use AIS among those with a high intention and low intention. Given that differences were also found by organisation affiliation these are also explored.

\subsection{Analysis of the belief structure}

This section presents the results of the survey, designed to elicit the subjective probability (or likelihood) and evaluation of all identified accessible outcomes. Table 3 shows averages and standard deviations of the scores for subjective beliefs and subjective evaluation.

Table 3. Mean comparison of strength of subjective belief and subjective evaluation regarding all accessible outcomes between high intenders and low intenders to use AIS $(n=122)$ 


\begin{tabular}{|c|c|c|c|c|c|c|}
\hline \multirow[t]{2}{*}{ Salient outcomes } & \multicolumn{3}{|c|}{ Subjective belief strength } & \multicolumn{3}{|c|}{ Subjective evaluation } \\
\hline & $\begin{array}{l}\text { Low } \\
\text { intention } \\
(n=45)\end{array}$ & $\begin{array}{l}\text { High } \\
\text { intention } \\
(n=77)\end{array}$ & Status & $\begin{array}{l}\text { Low } \\
\text { intention } \\
(\mathrm{n}=45)\end{array}$ & $\begin{array}{l}\text { High } \\
\text { intention } \\
(\mathrm{n}=77)\end{array}$ & Status \\
\hline $\begin{array}{l}\text { It can increase } \\
\text { productivity and } \\
\text { profitability of } \\
\text { innovations for } \\
\text { farmers }\end{array}$ & $\begin{array}{c}0.96 \\
(0.952)\end{array}$ & $\begin{array}{c}1.53 \\
(0.502)\end{array}$ & $*$ & $\begin{array}{l}1.44 \\
(0.624)\end{array}$ & $\begin{array}{l}1.69 \\
(0.520\end{array}$ & $*$ \\
\hline $\begin{array}{l}\text { It can increase the } \\
\text { attainment of food } \\
\text { security among } \\
\text { smallholder farmers }\end{array}$ & $\begin{array}{c}0.82 \\
(0.912)\end{array}$ & $\begin{array}{l}1.65 \\
(0.480)\end{array}$ & $* *$ & $\begin{array}{c}1.33 \\
(0.522)\end{array}$ & $\begin{array}{l}1.58 \\
(0.496)\end{array}$ & $*$ \\
\hline $\begin{array}{l}\text { It can enhance the } \\
\text { effectiveness and } \\
\text { sustainability of } \\
\text { innovations on rice }\end{array}$ & $\begin{array}{l}1.11 \\
(0.714)\end{array}$ & $\begin{array}{l}1.39 \\
(0.652)\end{array}$ & $*$ & $\begin{array}{c}1.29 \\
(0.506)\end{array}$ & $\begin{array}{l}1.56 \\
(0.525)\end{array}$ & $*$ \\
\hline $\begin{array}{l}\text { It can foster } \\
\text { capacity } \\
\text { development of } \\
\text { stakeholders } \\
\text { including farmers }\end{array}$ & $\begin{array}{c}1.24 \\
(0.609)\end{array}$ & $\begin{array}{c}1.52 \\
(0.620)\end{array}$ & $*$ & $\begin{array}{c}1.33 \\
(0.522)\end{array}$ & $\begin{array}{c}1.49 \\
(0.529)\end{array}$ & ns \\
\hline $\begin{array}{l}\text { It can improve } \\
\text { smallholder farmers' } \\
\text { access to input and } \\
\text { output markets. }\end{array}$ & $\begin{array}{c}1.07 \\
(0.539)\end{array}$ & $\begin{array}{l}1.39 \\
(0.588)\end{array}$ & $*$ & $\begin{array}{c}1.18 \\
(0.614)\end{array}$ & $\begin{array}{l}1.49 \\
(0.533)\end{array}$ & $*$ \\
\hline $\begin{array}{l}\text { It can enhance } \\
\text { experience sharing } \\
\text { and best practices } \\
\text { among different } \\
\text { actors }\end{array}$ & $\begin{array}{r}0.93 \\
(1.031)\end{array}$ & $\begin{array}{l}1.49 \\
(0.553)\end{array}$ & $* *$ & $\begin{array}{c}1.38 \\
(0.716)\end{array}$ & $\begin{array}{l}1.64 \\
(0.484)\end{array}$ & $*$ \\
\hline
\end{tabular}




\begin{tabular}{|c|c|c|c|c|c|c|}
\hline $\begin{array}{l}\text { It helps reduce } \\
\text { burden on any one } \\
\text { actor. }\end{array}$ & $\begin{array}{c}0.58 \\
(1.215)\end{array}$ & $\begin{array}{l}1.25 \\
(0.652)\end{array}$ & $* *$ & $\begin{array}{c}1.02 \\
(0.690)\end{array}$ & $\begin{array}{l}1.31 \\
(0.591)\end{array}$ & $*$ \\
\hline $\begin{array}{l}\text { It increases } \\
\text { agricultural } \\
\text { innovation actors' } \\
\text { (including farmers) } \\
\text { ability to innovate }\end{array}$ & $\begin{array}{c}0.73 \\
(0.939)\end{array}$ & $\begin{array}{l}1.32 \\
(0.785)\end{array}$ & $* *$ & $\begin{array}{c}1.13 \\
(0.661)\end{array}$ & $\begin{array}{l}1.42 \\
(0.496)\end{array}$ & $*$ \\
\hline $\begin{array}{l}\text { Coordination of } \\
\text { activities of the } \\
\text { various stakeholders } \\
\text { difficult }\end{array}$ & $\begin{array}{c}0.29 \\
(1.218)\end{array}$ & $\begin{array}{c}0.26 \\
(1.218)\end{array}$ & ns & $\begin{array}{c}-0.42 \\
(1.215)\end{array}$ & $\begin{array}{l}-0.34 \\
(1.210)\end{array}$ & ns \\
\hline $\begin{array}{l}\text { It is difficult to use } \\
\text { due to the diversity } \\
\text { of interests of } \\
\text { various actors }\end{array}$ & $\begin{array}{c}0.09 \\
(1.125)\end{array}$ & $\begin{array}{l}-0.45 \\
(0.994)\end{array}$ & $*$ & $\begin{array}{c}1.04 \\
(0.638)\end{array}$ & $\begin{array}{l}0.26 \\
(1.436)\end{array}$ & $*$ \\
\hline It is time consuming & $\begin{array}{c}-0.49 \\
(1.014)\end{array}$ & $\begin{array}{l}-0.19 \\
(1.225)\end{array}$ & ns & $\begin{array}{c}-0.29 \\
(1.014)\end{array}$ & $\begin{array}{l}-0.10 \\
(1.071)\end{array}$ & ns \\
\hline It is expensive & $\begin{array}{l}-0.11 \\
(1.049)\end{array}$ & $\begin{array}{l}-0.18 \\
(1.109)\end{array}$ & ns & $\begin{array}{c}-0.53 \\
(0.894)\end{array}$ & $\begin{array}{l}-0.17 \\
(1.322)\end{array}$ & $*$ \\
\hline $\begin{array}{l}\text { It is difficult to use } \\
\text { outside the } \\
\text { organisation's } \\
\text { policies }\end{array}$ & $\begin{array}{l}0.76( \\
1.026)\end{array}$ & $\begin{array}{l}0.83 \\
(1.069)\end{array}$ & ns & $\begin{array}{c}-0.82 \\
(0.716)\end{array}$ & $\begin{array}{l}-0.91 \\
(0.861)\end{array}$ & ns \\
\hline
\end{tabular}

Interesting trends in the outcome beliefs are evident. . In general, high intenders are more convinced that the use of an AIS approach will bring benefits to farmers. There is less disagreement on the potential disadvantages as shown in Table A2. Those with a high intention have a significantly stronger mean value for a number of beliefs including beliefs associated 
farmers to innovate (Table 3). Beliefs such as the AIS approach is difficult, are significantly higher for those with a low intentionand could impede research and extension actors use of an AIS approach.

Table 4. Mean comparison of strength of normative belief and motivation to comply regarding all accessible referents between those with high intention and weak intention to use AIS $(n=122)$

\begin{tabular}{|c|c|c|c|c|c|c|}
\hline \multirow[t]{2}{*}{ Referents } & \multicolumn{3}{|c|}{ Normative belief strength } & \multicolumn{3}{|c|}{ Motivation to comply } \\
\hline & $\begin{array}{l}\text { Low } \\
\text { intention ( } \mathrm{n} \\
=45)\end{array}$ & $\begin{array}{l}\text { High } \\
\text { intention (n } \\
=77 \text { ) }\end{array}$ & Status & $\begin{array}{l}\text { Low } \\
\text { intention } \\
(\mathrm{n}=45)\end{array}$ & $\begin{array}{l}\text { High } \\
\text { intention } \\
(\mathrm{n}=77)\end{array}$ & Status \\
\hline Employer & $\begin{array}{l}-0.69 \\
(0.701)\end{array}$ & $\begin{array}{l}1.17 \\
(1.093)\end{array}$ & $*$ & $\begin{array}{l}0.69 \\
(0.733)\end{array}$ & $\begin{array}{l}1.35 \\
(0.839)\end{array}$ & $* *$ \\
\hline Supervisor & $\begin{array}{l}0.27 \\
(0.780)\end{array}$ & $\begin{array}{l}0.71 \\
(1.145)\end{array}$ & $*$ & $\begin{array}{l}0.67 \\
(0.707)\end{array}$ & $\begin{array}{l}1.04 \\
(0.850\end{array}$ & $*$ \\
\hline $\begin{array}{l}\text { Professional } \\
\text { colleagues }\end{array}$ & $\begin{array}{l}0.53 \\
(0.786)\end{array}$ & $\begin{array}{l}1.06 \\
(1.056)\end{array}$ & $*$ & $\begin{array}{l}0.47 \\
(0.815)\end{array}$ & $\begin{array}{l}1.19 \\
(0.844)\end{array}$ & $* *$ \\
\hline Donors & $\begin{array}{l}0.44 \\
(0.841)\end{array}$ & $\begin{array}{l}0.91 \\
(1.194)\end{array}$ & $*$ & $\begin{array}{l}0.64 \\
(0.733)\end{array}$ & $\begin{array}{l}1.31 \\
(0.799)\end{array}$ & $* *$ \\
\hline Farmers & $\begin{array}{l}0.38 \\
(0.860)\end{array}$ & $\begin{array}{l}0.88 \\
(1.135)\end{array}$ & $*$ & $\begin{array}{l}0.31 \\
(0.949)\end{array}$ & $\begin{array}{l}0.79 \\
(0.922)\end{array}$ & $*$ \\
\hline Community leaders & $\begin{array}{l}0.36 \\
(0.883)\end{array}$ & $\begin{array}{l}0.55 \\
(1.165)\end{array}$ & ns & $\begin{array}{l}0.15 \\
(0.989)\end{array}$ & $\begin{array}{l}0.78 \\
(1.059)\end{array}$ & $*$ \\
\hline
\end{tabular}




\begin{tabular}{|l|l|l|l|l|l|l|}
\hline Family members & 0.31 & 0.57 & ns & -0.04 & 0.49 & $*$ \\
& $(1.062)$ & $(1.342)$ & & $(0.928)$ & $(1.154)$ & \\
\hline
\end{tabular}

\begin{tabular}{|c|c|c|c|c|c|c|}
\hline \multirow[t]{2}{*}{ Control beliefs } & \multicolumn{3}{|c|}{ Control belief strength } & \multicolumn{3}{|c|}{ Power of control } \\
\hline & $\begin{array}{l}\text { Low } \\
\text { intention ( } \mathrm{n} \\
=45)\end{array}$ & $\begin{array}{l}\text { High } \\
\text { intention (n } \\
=77 \text { ) }\end{array}$ & Status & $\begin{array}{l}\text { Low } \\
\text { intention } \\
(n=45)\end{array}$ & $\begin{array}{l}\text { High } \\
\text { intention } \\
(\mathrm{n}=77)\end{array}$ & Status \\
\hline $\begin{array}{l}\text { Have the knowledge } \\
\text { and skills on AIS } \\
\text { approach }\end{array}$ & $\begin{array}{l}-0.22 \\
(1.166)\end{array}$ & $\begin{array}{l}0.21 \\
(1.408)\end{array}$ & $*$ & $\begin{array}{l}0.80 \\
(1.036)\end{array}$ & $\begin{array}{l}1.62 \\
(0.726)\end{array}$ & $* *$ \\
\hline $\begin{array}{l}\text { Have adequate } \\
\text { financial resources } \\
\text { (eg from donors) to } \\
\text { use an AIS approach }\end{array}$ & $\begin{array}{l}-1.42 \\
(0.723)\end{array}$ & $\begin{array}{l}-0.90 \\
(1.324)\end{array}$ & $*$ & $\begin{array}{l}0.78 \\
(1.166)\end{array}$ & $\begin{array}{l}1.05 \\
(1.297)\end{array}$ & ns \\
\hline $\begin{array}{l}\text { Institutional policies } \\
\text { of my organization } \\
\text { discourage me from } \\
\text { the use of an AIS } \\
\text { approach }\end{array}$ & $\begin{array}{l}-0.47 \\
(1.217)\end{array}$ & $\begin{array}{l}-0.45 \\
(1.456)\end{array}$ & ns & $\begin{array}{l}0.38 \\
(1.154)\end{array}$ & $\begin{array}{l}0.62 \\
(1.367)\end{array}$ & ns \\
\hline
\end{tabular}

Significance status indicated as follows *denotes significant difference at the 0.05 level and

**denotes significance 0.001 level, standard deviation in parenthesis.

Table 4 shows that salient referents can have a positive influence on respondents' use of AIS approach in their activities. Consistently, it can be seen that respondents with a higher intention to use AIS perceived higher support or even pressure from their social referents such as employers, donors, colleagues, farmers and supervisors regarding the use of AIS approach. Moreover, those with a high intention have the strongest motivation to comply with social referents particularly employers, followed by colleagues and supervisors. In general,the professional network (employers, supervisor, colleagues, donors, farmers) seems more influential than the social network (family, community).

Table 5. Mean comparison of strength of control belief and power of control regarding all control factors between those with a high intention and weak intention to use AIS $(n=122)$ 


\begin{tabular}{|c|c|c|c|c|c|c|}
\hline $\begin{array}{l}\text { The poor } \\
\text { cooperation and } \\
\text { behaviour of other } \\
\text { actors will } \\
\text { discourage me from } \\
\text { adopting an AIS } \\
\text { approach }\end{array}$ & $\begin{array}{l}-0.27 \\
(1.468)\end{array}$ & $\begin{array}{l}-0.16 \\
(1.522)\end{array}$ & $\mathrm{ns}$ & $\begin{array}{l}1.00 \\
(1.066)\end{array}$ & $\begin{array}{l}1.13 \\
(1.207)\end{array}$ & $\mathrm{ns}$ \\
\hline $\begin{array}{l}\text { Cultural norms of } \\
\text { smallholder farmers } \\
\text { will discourage me } \\
\text { from using an AIS } \\
\text { approach }\end{array}$ & $\begin{array}{l}-0.36 \\
(1.111)\end{array}$ & $\begin{array}{l}0.08 \\
(1.393)\end{array}$ & ns & $\begin{array}{l}-0.11 \\
(1.049)\end{array}$ & $\begin{array}{l}-0.16 \\
(1.433)\end{array}$ & $\mathrm{ns}$ \\
\hline $\begin{array}{l}\text { The lack of } \\
\text { incentives from my } \\
\text { organisation will } \\
\text { discourage me from } \\
\text { adopting an AIS } \\
\text { approach in research } \\
\text { and extension. }\end{array}$ & $\begin{array}{l}0.71 \\
(1.079)\end{array}$ & $\begin{array}{l}0.55 \\
(1.391)\end{array}$ & $\mathrm{ns}$ & $\begin{array}{l}1.13 \\
(0.786)\end{array}$ & $\begin{array}{l}1.75 \\
(1.299)\end{array}$ & $*$ \\
\hline
\end{tabular}

Significance status indicated as follows *denotes significant difference at the 0.05 level and

**denotes significance 0.001 level, standard deviation in parenthesis

The results in Table 5 show that only a few of the control belief statements were significantly different between the two groups. Those with a high intention to use AIS have significantly different beliefs in relation to their knowledge and skills compared to low intenders. High intenders believe they have adequate knowledge and skills in the use of AIS than low intenders.

Further, the results show that not having adequate financial resources can act as a constraining factor for respondents' use of an AIS approach. The majority of respondents disagreed that they have adequate financial resources to use an AIS approach. The lack of incentives may also deter those with a low intention to use AIS approach, however, it may deter more those with a higher intention to use AIS than their counterparts. This is possibly due to the fact that low intenders may not respond to incentives from their organisations for using AIS, as they may have other factors that might still deter them; while high intenders may consider incentives 
from their organisations an important factor that could sharpen their motivation and provide the enabling environment for them to use AIS.

\section{Beliefs by organisation}

A further disaggregation of the results by organisation show that respondents have different beliefs associated with the use of AIS. Interestingly, NGOs have a significantly higher positive mean value compared to their counterparts (SLARI and MAFFS) i.e. for key beliefs such as attainment of food security for farmers, access to input and output markets for smallholders and farmers' ability to innovate $(\mathrm{P}=<0.05)$. This may not be surprising considering many NGOs have dedicated projects/programmes associated specifically to such outcomes (Table A6) and are also already already working more with other organisations.

Table A7 (in Appendix) shows the influence salient referents have on respondents also differs by organisation. Interestingly MAFFS has the highest mean values for key social referents including employer, supervisor and donors. These are significantly higher than NGOs though these have higher means comparatively than for SLARI. Moreover, NGOs perceive greater social pressure from professional colleagues than MAFFS and SLARI (Table A7).

Table A8 (in Appendix) shows that only a few of the control belief statements were significantly different between the three groups. For example, MAFFS feel they have a lower perceived level of control with respect to knowledge and skills than SLARI $(\mathrm{P}=<0.05)$. Moreover, the MAFFS also has a significantly higher value for the lack of incentives suggesting this is an impediment for the use of AIS. NGOs also have a significantly higher value than SLARI.

\section{Discussion and conclusions}

This study investigated, the cognitive foundations of research and extension professionals' intention to use AIS approach (through the framework of the theory of planned behaviour). It is clear that the socio-economic characteristics of research and extension professionals influence their intention and beliefs regarding the use of AIS approach. The findings with respect to respondents' socio-economic characteristics have shown the majority are males, mostly within the age brackets of 31-40 years. Interestingly, females had a higher intention to 
use an AIS approach, as did younger respondents. The majority of respondents are educated to Bachelor's and Master's levels and respondents with education levels both higher and lower than this showed lower strengths of intention.

Professionals with a high intention to use AIS approach have significantly stronger beliefs associated with the benefits of using the approach, including its ease of use, and the benefits an AIS approach is likely to have on smallholders' food security and their ability to innovate. Those with a high intention to use an AIS approach also perceive stronger social pressure from key social referents that positively influence the use of AIS such as colleagues, employers and supervisors. This largely suggests salient referents can influence respondents' intention and subsequently their use of an AIS approach in research and extension programmes in practice. Most of the beliefs associated with a low intention to use AIS approach are consistent with the literature on some of the key challenges that could deter the use of an AIS approach in research and extension as indicated by Klerkx et al., (2012) and Hall (2007). This means that special attention needs to be paid to these potential impediments in a bid to circumvent their effect on the potential use of an AIS approach among research and extension professionals in Sierra Leone (and beyond).

While higher education could be expected to be associated with stronger belief of research and extension personnel in the usefulness of an AIS approach, our results remain ambiguous about this. Differences between average intention to use AIS between different education levels seem small, often non-significant, and also not linear (it is not that the higher the education level the higher the intention). It is highly likely that the level of education of respondents have little or no influence on their decisions to (not) use AIS approaches. In fact, those educated to MSc and $\mathrm{PhD}$ levels had less intention than BSc and Certificate level graduates. This possibly reflects the fact that respondents in SLARI, who seem to be more educated than their counterparts in MAFFS and NGOs had the least intention to use AIS approaches.

These results generally show that research and extension actors hold positive intentions towards the use of an AIS approach. The average intention decreases with age, which suggests that younger people are more likely to adapt to new ways of working, while older people are more likely to adhere to the traditional models which fall within their comfort zones. Younger professionals are less likely to have settled for traditional approaches compared to their older counterparts who may find it difficult to change. The lowest intention is among professionals from SLARI and can also be attributed to the fact that they have a higher percentage of older 
professionals than the MAFFS. This may also help explain why the MAFFS has the highest intention, as their staff are younger than those from SLARI and NGOs.

.In general, the study highlighted that the use of an AIS approach is mainly driven by research and extension professionals' beliefs in the benefits the approach will bring, and by having a social (and especially professional) network that encourages the use of such an approach. It is less driven by external drivers, although lack of skills and expertise may inhibit (good) use of the approach. The study also highlighted the need for national innovation systems to target younger professionals as key conduits for a more impactful use of the approach as opposed to their older counterparts. On the other hand, it also implies that more effort is required to have the latter, who are more likely to be in positions of senior management, accommodate the use of innovative approaches such as AIS in the design and implementation of agricultural development programmes. Also, the importance of the socio-economic characteristics of research and extension professionals in influencing their ability to use AIS has been highlighted; suggesting the need to consider these in planning successful AIS approaches.

In Sierra Leone, findings from this study suggest the need for facilitating institutional change in research and extension organisations in order that all cadres of professionals align their activities in favour of AIS approaches. Also, the fact that professionals hold very positive intentions towards the use of the approach especially at MAFFS and NGOs is an important entry point in facilitating the effective use of the approach in research and extension programmes. This is a strong signal that if other conditions are favourable, the use of the approach in Sierra Leone could possibly be actualized especially among extension professionals. However, the weak intentions among SLARI professionals point to the need for capacity strengthening and putting in place mechanisms to change behaviour among SLARI professionals who currently have the least intention to use an AIS approach. This is especially important as the use of AIS approaches in the country is currently very low (in practice) due to factors related to technical capacities and financial resources in both public and private sector institutions. 
818 Acknowledgements

819 The authors wish to thank the Commonwealth Scholarship Commission, UK for funding the 820 study. We would also like to thank research and extension professionals in Sierra Leone for 821 sparing their precious time to participate in this study. 


\section{Appendix A}

Table A1: Socio-economic characteristics of respondents disaggregated by organisation

\begin{tabular}{|c|c|c|c|c|c|c|c|c|c|}
\hline \multirow[t]{2}{*}{$\begin{array}{l}\text { Soico-economic } \\
\text { Characteristics }\end{array}$} & \multirow[t]{2}{*}{ Category } & \multicolumn{2}{|c|}{ MAFFS $(n=45)$} & \multicolumn{2}{|c|}{ NGOs $(n=42)$} & \multicolumn{2}{|c|}{ SLARI $(n=35)$} & \multicolumn{2}{|c|}{ TOTAL $(n=122)$} \\
\hline & & $\begin{array}{l}\text { Frequency } \\
\text { (F) }\end{array}$ & $\begin{array}{l}\text { Percentag } \\
\text { e }(\%)\end{array}$ & $\mathbf{F}$ & $\%$ & $\mathbf{F}$ & $\%$ & $\mathbf{F}$ & $\%$ \\
\hline \multicolumn{10}{|l|}{ Sex } \\
\hline & Male & 35 & 77.8 & 37 & 88.1 & 33 & 94.3 & 105 & 86.1 \\
\hline & Female & 10 & 22.2 & 5 & 11.9 & 2 & 5.7 & 17 & 13.9 \\
\hline \multicolumn{10}{|l|}{ Age } \\
\hline & $18-30 y r s$ & 7 & 15.6 & 6 & 14.3 & 5 & 14.3 & 18 & 14.8 \\
\hline & $31-40 y r s$ & 19 & 42.2 & 17 & 40.4 & 10 & 28.6 & 46 & 37.7 \\
\hline & $41-50 \mathrm{yrs}$ & 14 & 31.1 & 6 & 14.3 & 7 & 20.0 & 27 & 22.1 \\
\hline & $\begin{array}{l}\text { Above } \\
50 \mathrm{yrs}\end{array}$ & 5 & 11.1 & 13 & 31.0 & 13 & 37.1 & 31 & 25.4 \\
\hline \multicolumn{10}{|l|}{ Education } \\
\hline & $\begin{array}{l}\text { College } \\
\text { Certificate }\end{array}$ & 6 & 13.3 & 9 & 21.4 & 2 & 5.7 & 17 & 13.9 \\
\hline & $\begin{array}{l}\text { College } \\
\text { Diploma }\end{array}$ & 11 & 24.4 & 5 & 11.9 & 7 & 20.0 & 23 & 18.9 \\
\hline & $\begin{array}{l}\text { Bachelor's } \\
\text { Degree }\end{array}$ & 22 & 48.9 & 20 & 47.6 & 9 & 25.7 & 51 & 41.8 \\
\hline & $\begin{array}{l}\text { Master's } \\
\text { degree }\end{array}$ & 5 & 11.1 & 8 & 19.0 & 15 & 42.9 & 28 & 23.0 \\
\hline & $\mathrm{PhD}$ & 1 & 2.2 & 0 & 0.0 & 2 & 5.7 & 3 & 2.5 \\
\hline \multicolumn{10}{|l|}{$\begin{array}{l}\text { Other sources of } \\
\text { income in } \\
\text { addition to job }\end{array}$} \\
\hline & Yes & 14 & 31.1 & 25 & 59.5 & 8 & 22.9 & 47 & 38.5 \\
\hline & No & 31 & 68.9 & 17 & 40.5 & 27 & 77.1 & 75 & 61.5 \\
\hline \multicolumn{10}{|l|}{$\begin{array}{l}\text { Participation in } \\
\text { Inter-agency } \\
\text { meetings }\end{array}$} \\
\hline & Yes & 36 & 80.0 & 42 & 100.0 & 15 & 42.9 & 93 & 76.2 \\
\hline & No & 9 & 20.0 & 0 & 0.0 & 18 & 51.4 & 27 & 22.1 \\
\hline & $\begin{array}{l}\text { Not } \\
\text { available }\end{array}$ & 0 & 0.0 & 0 & 0.0 & 2 & 5.7 & 2 & 1.6 \\
\hline \multicolumn{10}{|l|}{$\begin{array}{l}\text { Attended training } \\
\text { related to role in } \\
\text { last } 12 \text { Months }\end{array}$} \\
\hline & Yes & 39 & 86.7 & 40 & 95.2 & 21 & 60.0 & 100 & 82.0 \\
\hline & No & 6 & 13.3 & 2 & 4.8 & 14 & 40.0 & 22 & 18.0 \\
\hline \multicolumn{10}{|l|}{$\begin{array}{l}\text { Membership in } \\
\text { professional } \\
\text { networks }\end{array}$} \\
\hline & Yes & 10 & 22.2 & 31 & 73.8 & 8 & 22.9 & 49 & 40.2 \\
\hline & No & 35 & 77.8 & 11 & 26.2 & 27 & 77.1 & 73 & 59.8 \\
\hline \multicolumn{10}{|l|}{$\begin{array}{l}\text { Experience in } \\
\text { research and } \\
\text { extension }\end{array}$} \\
\hline & 1-10yrs & 31 & 68.9 & 29 & 69.0 & 18 & 51.4 & 78 & 63.9 \\
\hline & $11-20 y r s$ & 8 & 17.8 & 10 & 23.8 & 7 & 20.0 & 25 & 20.5 \\
\hline & 21-30yrs & 4 & 8.9 & 0 & 0.0 & 4 & 11.4 & 8 & 6.6 \\
\hline & $31-40 y r s$ & 2 & 4.4 & 3 & 7.1 & 6 & 17.1 & 11 & 9.0 \\
\hline
\end{tabular}




\begin{tabular}{|l|l|l|l|l|l|l|l|l|l|}
\hline $\begin{array}{l}\text { Length of service } \\
\text { in current } \\
\text { organisation }\end{array}$ & & & & & & & & & \\
& & & & & & & & \\
& $1-10 \mathrm{yrs}$ & 31 & 68.9 & 42 & 100.0 & 22 & 62.9 & 95 & $\mathbf{7 7 . 9}$ \\
\hline & $11-20 \mathrm{yrs}$ & 7 & 15.6 & 0 & 0.0 & 2 & 5.7 & 9 & $\mathbf{7 . 4}$ \\
\hline & $21-30 \mathrm{yrs}$ & 2 & 4.4 & 0 & 0.0 & 5 & 14.3 & 7 & $\mathbf{5 . 7}$ \\
\hline $\begin{array}{l}\text { Speak } \\
\text { Community }\end{array}$ & $31-40 \mathrm{yrs}$ & 5 & 11.1 & 0 & 0.0 & 6 & 17.1 & 11 & $\mathbf{9 . 0}$ \\
\hline & & & & & & & & \\
\hline & & & & & & & & & \\
\hline $\begin{array}{l}\text { Language a farming } \\
\text { background }\end{array}$ & Yes & 31 & 68.9 & 38 & 90.5 & 23 & 65.7 & 92 & $\mathbf{7 5 . 4}$ \\
\hline & Yes & 14 & 31.1 & 4 & 9.5 & 12 & 34.3 & 30 & $\mathbf{2 4 . 6}$ \\
\hline & No & 8 & & & & & & & \\
\hline
\end{tabular}

Source: Field Survey, 2016/17

853 Table A2. Socio-economic characteristics and mean comparison of intention to use AIS

variables $(\mathbf{n}=\mathbf{1 2 2})$

\begin{tabular}{|c|c|}
\hline & Intention $^{\mathrm{i}}$ \\
\hline \multicolumn{2}{|l|}{ Sex } \\
\hline Male $(n=105)$ & $0.591(0.494)^{\mathrm{a}}$ \\
\hline Female $(n=17)$ & $0.882(0.332)$ \\
\hline \multicolumn{2}{|l|}{ Age } \\
\hline $18-30$ years $(n=18)$ & $0.889(0.323)^{b}$ \\
\hline $31-40$ years $(n=46)$ & $0.717(0.455)$ \\
\hline $41-50$ years $(n=27)$ & $0.556(0.506)^{\mathrm{c}}$ \\
\hline Above 50 years $(n=31)$ & $0.419(0.501)$ \\
\hline \multicolumn{2}{|l|}{ Education } \\
\hline College certificate $(n=17)$ & $0.647(0.492)^{d}$ \\
\hline College diploma $(\mathrm{n}=23)$ & $0.478(0.510)^{d}$ \\
\hline Bachelor's degree $(\mathrm{n}=51)$ & $0.765(0.428)^{\mathrm{e}}$ \\
\hline Master's degree $(n=28)$ & $0.536(0.507)$ \\
\hline $\mathrm{PhD}(\mathrm{n}=3)$ & $0.333(0.577)$ \\
\hline \multicolumn{2}{|l|}{ Membership in professional networks } \\
\hline Member of professional network $(\mathrm{n}=49)$ & $0.714(0.456)^{\mathrm{f}}$ \\
\hline Not member $(n=73)$ & $0.575(0.498)$ \\
\hline
\end{tabular}




\begin{tabular}{|l|l|}
\hline Organisation & \\
\hline MAFF $(\mathrm{n}=45)$ & $0.756(0.435)^{\mathrm{g}}$ \\
\hline SLARI $(\mathrm{n}=35)$ & $0.427(0.502)$ \\
\hline NGO $(\mathrm{n}=42)$ & $0.6667(0.477)$ \\
\hline Category of work & \\
\hline Research work $(\mathrm{n}=64)$ & $0.522(0.505)^{\mathrm{h}}$ \\
\hline Extension work $(\mathrm{n}=65)$ & $0.697(0.464)$ \\
\hline Farming background & \\
\hline Yes $(\mathrm{n}=113)$ & $0.620(0.487)$ \\
\hline No (n=9) & $0.778(0.440)$ \\
\hline
\end{tabular}

a significant difference between male and female $(\mathrm{p}<0.05)$

856 b significantly different between $18-30$ years and above 50 years $(\mathrm{p}<0.001)$

d significantly different between college diploma and $\mathrm{PhD}$ and college certificate and $\mathrm{PhD}(\mathrm{p}$

$859<0.05)$

e significantly different between bachelor and $\mathrm{PhD}(\mathrm{p}<0.05)$

861 f significantly different between members and non-members $(\mathrm{p}<0.001)$

i Means scores and standard deviation on a scale from 0(unfavourable towards use of AIS) and 
Table A6. Mean comparison of subjective beliefs and evaluation of accessible outcomes

872 to use AIS between different organisations $(\mathbf{n}=122)$

\begin{tabular}{|c|c|c|c|c|c|c|c|c|}
\hline \multirow[t]{2}{*}{ Salient outcomes } & \multicolumn{4}{|c|}{ Subjective belief strength } & \multicolumn{4}{|c|}{ Subjective evaluation } \\
\hline & MAFFS & SLARI & NGO & Status & MAFFS & SLARI & NGO & Status \\
\hline $\begin{array}{l}\text { It can increase } \\
\text { productivity and } \\
\text { profitability of } \\
\text { innovations for } \\
\text { farmers }\end{array}$ & $\begin{array}{l}1.47 \\
(0.588)\end{array}$ & $\begin{array}{l}1.23 \\
(0.598)\end{array}$ & $\begin{array}{l}1.24 \\
(0.983)\end{array}$ & ns & $\begin{array}{l}1.58 \\
(0.621)\end{array}$ & $\begin{array}{l}1.51 \\
(0.612)\end{array}$ & $\begin{array}{l}1.69 \\
(0.468)\end{array}$ & ns \\
\hline $\begin{array}{l}\text { It can increase } \\
\text { the attainment of } \\
\text { food security } \\
\text { among } \\
\text { smallholder } \\
\text { farmers }\end{array}$ & $\begin{array}{l}1.42 \\
(0.723)\end{array}$ & $\begin{array}{l}1.14 \\
(0.648)\end{array}$ & $\begin{array}{l}1.43 \\
(0.914)\end{array}$ & ns & $\begin{array}{l}1.42 \\
(0.499)\end{array}$ & $\begin{array}{l}1.34 \\
(0.539)\end{array}$ & $\begin{array}{l}1.69 \\
(0.468)\end{array}$ & $\begin{array}{l}\mathrm{c}>\mathrm{a} * * \\
\mathrm{c}>\mathrm{b} * *\end{array}$ \\
\hline $\begin{array}{l}\text { It can enhance } \\
\text { the effectiveness } \\
\text { and } \\
\text { sustainability of } \\
\text { innovations on } \\
\text { rice }\end{array}$ & $\begin{array}{l}1.27 \\
(0.863)\end{array}$ & $\begin{array}{l}1.14 \\
(0.550)\end{array}$ & $\begin{array}{l}1.43 \\
(0.547)\end{array}$ & ns & $\begin{array}{l}1.53 \\
(0.548)\end{array}$ & $\begin{array}{l}1.03 \\
(0.296)\end{array}$ & $\begin{array}{l}1.74 \\
(0.445)\end{array}$ & $\begin{array}{l}\mathrm{a}>\mathrm{b} * * * \\
\mathrm{c}>\mathrm{b} * * *\end{array}$ \\
\hline $\begin{array}{l}\text { It can foster } \\
\text { capacity } \\
\text { development of } \\
\text { stakeholders } \\
\text { including } \\
\text { farmers }\end{array}$ & $\begin{array}{l}1.27 \\
(0.654)\end{array}$ & $\begin{array}{l}1.29 \\
(0.519)\end{array}$ & $\begin{array}{l}1.69 \\
(0.604)\end{array}$ & $\begin{array}{l}\mathrm{c}>\mathrm{a} * * \\
\mathrm{c}>\mathrm{b} * *\end{array}$ & $\begin{array}{l}1.31 \\
(0.514)\end{array}$ & $\begin{array}{l}1.43 \\
(0.588)\end{array}$ & $\begin{array}{l}1.57 \\
(0.501)\end{array}$ & $c>a^{*}$ \\
\hline $\begin{array}{l}\text { It can improve } \\
\text { smallholder } \\
\text { farmers' access }\end{array}$ & $\begin{array}{l}1.20 \\
(0.548)\end{array}$ & $\begin{array}{l}1.14 \\
(0.692)\end{array}$ & $\begin{array}{l}1.45 \\
(0.504)\end{array}$ & $\begin{array}{l}c>a^{*} \\
c>b *\end{array}$ & $\begin{array}{l}1.20 \\
(0.588)\end{array}$ & $\begin{array}{l}1.40 \\
(0.651)\end{array}$ & $\begin{array}{l}1.55 \\
(504)\end{array}$ & c>a** \\
\hline
\end{tabular}




\begin{tabular}{|c|c|c|c|c|c|c|c|c|}
\hline $\begin{array}{l}\text { to input and } \\
\text { output markets. }\end{array}$ & & & & & & & & \\
\hline $\begin{array}{l}\text { It can enhance } \\
\text { experience } \\
\text { sharing and best } \\
\text { practices among } \\
\text { different actors }\end{array}$ & $\begin{array}{l}1.24 \\
(0.529)\end{array}$ & $\begin{array}{l}1.40 \\
(0.523)\end{array}$ & $\begin{array}{l}1.24 \\
(1.165)\end{array}$ & $\mathrm{ns}$ & $\begin{array}{l}1.38 \\
(0.576)\end{array}$ & $\begin{array}{l}1.43 \\
(0.558)\end{array}$ & $\begin{array}{l}1.81 \\
(0.552)\end{array}$ & $\begin{array}{l}\mathrm{c}>\mathrm{a}^{* *} \\
\mathrm{c}>\mathrm{b}^{* *}\end{array}$ \\
\hline $\begin{array}{l}\text { It helps reduce } \\
\text { burden on any } \\
\text { one actor. }\end{array}$ & $\begin{array}{l}0.93 \\
(0.939))\end{array}$ & $\begin{array}{l}1.43 \\
(0.553)\end{array}$ & $\begin{array}{l}0.74 \\
(1.127)\end{array}$ & $\begin{array}{l}b>a * * \\
b>c * *\end{array}$ & $\begin{array}{l}1.02 \\
(0.621)\end{array}$ & $\begin{array}{l}1.34 \\
(0.539)\end{array}$ & $\begin{array}{l}1.29 \\
(0.708)\end{array}$ & $\mathrm{b}>\mathrm{a} * *$ \\
\hline $\begin{array}{l}\text { It increases } \\
\text { agricultural } \\
\text { innovation } \\
\text { actors (including } \\
\text { farmers) ability } \\
\text { to innovate }\end{array}$ & $\begin{array}{l}1.08 \\
(0.866)\end{array}$ & $\begin{array}{l}0.97 \\
(0.891)\end{array}$ & $\begin{array}{l}1.31 \\
(0.897)\end{array}$ & ns & $\begin{array}{l}1.16 \\
(0.638)\end{array}$ & $\begin{array}{l}1.34 \\
(0.539)\end{array}$ & $\begin{array}{l}1.45 \\
(0.504)\end{array}$ & $c>a^{*}$ \\
\hline $\begin{array}{l}\text { Coordination of } \\
\text { activities of the } \\
\text { various } \\
\text { stakeholders } \\
\text { difficult }\end{array}$ & $\begin{array}{l}0.40 \\
(1.176)\end{array}$ & $\begin{array}{l}-0.09 \\
(1.314)\end{array}$ & $\begin{array}{l}0.43 \\
(1.129)\end{array}$ & ns & $\begin{array}{l}-0.29 \\
(1.160)\end{array}$ & $\begin{array}{l}-0.49 \\
(1.095)\end{array}$ & $\begin{array}{l}1.129 \\
(1.358)\end{array}$ & $\mathrm{ns}$ \\
\hline $\begin{array}{l}\text { It is difficult to } \\
\text { use due to the } \\
\text { diversity of } \\
\text { interests of } \\
\text { various actors }\end{array}$ & $\begin{array}{l}-0.22 \\
(1.166)\end{array}$ & $\begin{array}{l}-0.49 \\
(0.812)\end{array}$ & $\begin{array}{l}-0.17 \\
(1.167)\end{array}$ & ns & $\begin{array}{l}0.69 \\
(1.258)\end{array}$ & $\begin{array}{l}0.60 \\
(1.063)\end{array}$ & $\begin{array}{l}0.36 \\
(1.411)\end{array}$ & $\mathrm{ns}$ \\
\hline $\begin{array}{l}\text { It is time } \\
\text { consuming }\end{array}$ & $\begin{array}{l}-0.58 \\
(1.138)\end{array}$ & $\begin{array}{l}-0.23 \\
(1.031)\end{array}$ & $\begin{array}{l}-0.07 \\
(1.237)\end{array}$ & ns & $\begin{array}{l}0.00 \\
(1.066)\end{array}$ & $\begin{array}{l}-0.17 \\
(1.043)\end{array}$ & $\begin{array}{l}-0.36 \\
(1.032)\end{array}$ & $\mathrm{ns}$ \\
\hline It is expensive & $\begin{array}{l}-0.20 \\
(1.179)\end{array}$ & $\begin{array}{l}-0.34 \\
(1.027)\end{array}$ & $\begin{array}{l}-0.05 \\
(1.011)\end{array}$ & ns & $\begin{array}{l}-0.04 \\
(1.261)\end{array}$ & $\begin{array}{l}-0.57 \\
(1.145)\end{array}$ & $\begin{array}{l}0.26 \\
(1.149)\end{array}$ & $\mathrm{c}>\mathrm{b}^{* *}$ \\
\hline
\end{tabular}




\begin{tabular}{|c|c|c|c|c|c|c|c|c|}
\hline $\begin{array}{l}\text { It is difficult to } \\
\text { use outside the } \\
\text { organisation's } \\
\text { policies }\end{array}$ & $\begin{array}{l}0.82 \\
(1.093)\end{array}$ & $\begin{array}{l}0.69 \\
(0.832)\end{array}$ & $\begin{array}{c}0.88 \\
(1.173)\end{array}$ & $\mathrm{ns}$ & $\begin{array}{l}-0.62 \\
(1.093)\end{array}$ & $\begin{array}{l}-0.86 \\
(0.648)\end{array}$ & $\begin{array}{l}-1.17 \\
(0.377)\end{array}$ & $\begin{array}{l}a>c * * \\
b>c * *\end{array}$ \\
\hline
\end{tabular}

873 Significance status indicated as follows *denotes significant difference at the 0.10 level, $* *$

874 denotes significance at the 0.05 level and $* * *$ denotes significance 0.001 level, standard

875 deviation in parenthesis. $a=$ MAFFS, $b=$ SLARI, C=NGO. Only significant differences

876 highlighted otherwise ns (not significant)/not shown. > denotes significantly greater than.

877 Table A7. Mean comparison of strength of normative belief and motivation to comply

878 regarding all accessible referents between different organisations $(\mathbf{n}=122)$

\begin{tabular}{|c|c|c|c|c|c|c|c|c|}
\hline \multirow[t]{2}{*}{ Referents } & \multicolumn{4}{|c|}{ Normative belief strength } & \multicolumn{4}{|c|}{ Motivation to comply } \\
\hline & MAFFS & SLARI & NGO & Status & MAFFS & SLARI & $\mathrm{NGO}$ & Status \\
\hline Employer & $\begin{array}{l}1.33 \\
(0.739)\end{array}$ & $\begin{array}{l}0.40 \\
(1.288)\end{array}$ & $\begin{array}{l}1.12 \\
(0.705)\end{array}$ & $\begin{array}{l}a>b * * * \\
c>b\end{array}$ & $\begin{array}{l}1.33 \\
(0.798)\end{array}$ & $\begin{array}{l}0.80 \\
(1.079)\end{array}$ & $\begin{array}{l}1.12 \\
(0.633)\end{array}$ & $a>b$ \\
\hline Supervisor & $\begin{array}{l}0.87 \\
(1.306)\end{array}$ & $\begin{array}{l}-0.14 \\
(1.115)\end{array}$ & $\begin{array}{l}0.79 \\
(0.682)\end{array}$ & $\begin{array}{l}\mathrm{a}>\mathrm{b} . * * * \\
\mathrm{c}>\mathrm{b} . * * *\end{array}$ & $\begin{array}{l}1.16 \\
(0.824)\end{array}$ & $\begin{array}{l}0.66 \\
(1.083)\end{array}$ & $\begin{array}{l}0.83 \\
(0.377)\end{array}$ & $\begin{array}{l}a>b \\
c>b^{*}\end{array}$ \\
\hline $\begin{array}{l}\text { Professional } \\
\text { colleagues }\end{array}$ & $\begin{array}{l}0.89 \\
(1.027)\end{array}$ & $\begin{array}{l}0.49 \\
(0.981)\end{array}$ & $\begin{array}{l}1.17 \\
(0.881)\end{array}$ & $\mathrm{c}>\mathrm{b}^{* * *}$ & $\begin{array}{l}0.98 \\
(0.917)\end{array}$ & $\begin{array}{l}0.71 \\
(0.860)\end{array}$ & $\begin{array}{l}1.05 \\
(0.909)\end{array}$ & $\mathrm{ns}$ \\
\hline Donors & $\begin{array}{l}1.22 \\
(0.927)\end{array}$ & $\begin{array}{l}0.20 \\
(1.106)\end{array}$ & $\begin{array}{l}0.67 \\
(1.052)\end{array}$ & $\begin{array}{l}a>b . * * * \\
a>c\end{array}$ & $\begin{array}{l}1.27 \\
(0.688)\end{array}$ & $\begin{array}{l}0.83 \\
(1.043)\end{array}$ & $\begin{array}{l}1.05 \\
(0.795)\end{array}$ & $a>b$ \\
\hline Farmers & $\begin{array}{l}0.73 \\
(1.053)\end{array}$ & $\begin{array}{l}0.37 \\
(0.942)\end{array}$ & $\begin{array}{l}0.93 \\
(1.135)\end{array}$ & ns & $\begin{array}{l}0.73 \\
(0.915)\end{array}$ & $\begin{array}{l}0.74 \\
(0.950)\end{array}$ & $\begin{array}{l}0.38 \\
(0.987)\end{array}$ & ns \\
\hline $\begin{array}{l}\text { Community } \\
\text { leaders }\end{array}$ & $\begin{array}{l}0.51 \\
(1.058)\end{array}$ & $\begin{array}{l}0.29 \\
(1.126)\end{array}$ & $\begin{array}{l}0.60 \\
(1.037)\end{array}$ & ns & $\begin{array}{l}0.67 \\
(0.953\end{array}$ & $\begin{array}{l}0.34 \\
(1.110)\end{array}$ & $\begin{array}{l}0.63 \\
(1.172)\end{array}$ & ns \\
\hline $\begin{array}{l}\text { Family } \\
\text { members }\end{array}$ & $\begin{array}{l}0.47 \\
(1.290)\end{array}$ & $\begin{array}{l}0.14 \\
(1.287)\end{array}$ & $\begin{array}{l}0.76 \\
(1.122)\end{array}$ & ns & $\begin{array}{l}0.49 \\
(1.079)\end{array}$ & $\begin{array}{l}0.29 \\
(1.126)\end{array}$ & $\begin{array}{l}0.10 \\
(1.100)\end{array}$ & ns \\
\hline
\end{tabular}

Significance status indicated as follows *denotes significant difference at the 0.10 level, **

denotes significance at the 0.05 level and $* * *$ denotes significance 0.001 level, standard 
Table A8. Mean comparison of strength of control belief and power of control motivation to comply regarding all accessible control factors for different organisations (n=122)

\begin{tabular}{|c|c|c|c|c|c|c|c|c|}
\hline \multirow[t]{2}{*}{ Control factors } & \multicolumn{4}{|c|}{ Strength of control belief } & \multicolumn{4}{|c|}{ Power of control } \\
\hline & MAFFS & SLARI & NGO & Status & MAFFS & SLARI & NGO & Status \\
\hline $\begin{array}{l}\text { Have the } \\
\text { knowledge and } \\
\text { skills on AIS } \\
\text { approach }\end{array}$ & $\begin{array}{l}0.29 \\
(1.342)\end{array}$ & $\begin{array}{l}-0.29 \\
(1.250)\end{array}$ & $\begin{array}{l}0.7 \\
(1.369)\end{array}$ & ns & $\begin{array}{l}1.58 \\
(0.839)\end{array}$ & $\begin{array}{l}1.20 \\
(0.719 \\
)\end{array}$ & $\begin{array}{l}1.14 \\
(1.138)\end{array}$ & $a>b^{*}$ \\
\hline $\begin{array}{l}\text { Have adequate } \\
\text { financial } \\
\text { resources (eg } \\
\text { from donors) to } \\
\text { use an AIS } \\
\text { approach }\end{array}$ & $\begin{array}{l}-0.91 \\
(1.345)\end{array}$ & $\begin{array}{l}-1.23 \\
(1.239)\end{array}$ & $\begin{array}{l}-1.17 \\
(0.853)\end{array}$ & ns & $\begin{array}{l}0.93 \\
(1.372)\end{array}$ & $\begin{array}{l}1.00 \\
(1.138 \\
)\end{array}$ & $\begin{array}{l}0.93 \\
(1.237)\end{array}$ & Ns \\
\hline $\begin{array}{l}\text { Institutional } \\
\text { policies of my } \\
\text { organization } \\
\text { discourage me } \\
\text { from the use of } \\
\text { an AIS approach }\end{array}$ & $\begin{array}{l}-0.64 \\
(1.417)\end{array}$ & $\begin{array}{l}-0.40 \\
(1.241)\end{array}$ & $\begin{array}{l}-0.31 \\
(1.423)\end{array}$ & ns & $\begin{array}{l}0.91 \\
(1.345)\end{array}$ & $\begin{array}{l}0.54 \\
(1.094 \\
)\end{array}$ & $\begin{array}{l}0.12 \\
(1.292)\end{array}$ & $a>c^{* *}$ \\
\hline $\begin{array}{l}\text { The poor } \\
\text { cooperation and } \\
\text { behaviour of } \\
\text { other actors will } \\
\text { discourage me } \\
\text { from adopting an } \\
\text { AIS approach }\end{array}$ & $\begin{array}{l}-0.22 \\
(1.521)\end{array}$ & $\begin{array}{l}0.09 \\
(1.422)\end{array}$ & $\begin{array}{l}-0.40 \\
(1.531)\end{array}$ & ns & $\begin{array}{l}1.33 \\
(0.977)\end{array}$ & $\begin{array}{l}0.94 \\
(1.327 \\
)\end{array}$ & $\begin{array}{l}0.93 \\
(1.156)\end{array}$ & ns \\
\hline $\begin{array}{l}\text { Cultural norms of } \\
\text { smallholder } \\
\text { farmers will }\end{array}$ & $\begin{array}{l}-0.09 \\
(1.490)\end{array}$ & $\begin{array}{l}0.14 \\
(1.061)\end{array}$ & $\begin{array}{l}-0.26 \\
(1.289)\end{array}$ & ns & $\begin{array}{l}-0.16 \\
(1.429)\end{array}$ & $\begin{array}{l}-0.31 \\
(0.932 \\
)\end{array}$ & $\begin{array}{l}0.02 \\
(1.423)\end{array}$ & ns \\
\hline
\end{tabular}




\begin{tabular}{|c|c|c|c|c|c|c|c|c|}
\hline $\begin{array}{l}\text { discourage me } \\
\text { from using an } \\
\text { AIS approach }\end{array}$ & & & & & & & & \\
\hline $\begin{array}{l}\text { The lack of } \\
\text { incentives from } \\
\text { my organisation } \\
\text { will discourage } \\
\text { me from adopting } \\
\text { an AIS approach } \\
\text { in research and } \\
\text { extension. }\end{array}$ & $\begin{array}{l}0.71 \\
(1.308)\end{array}$ & $\begin{array}{l}0.31 \\
(1.183)\end{array}$ & $\begin{array}{l}0.74 \\
(1.326)\end{array}$ & $\mathrm{ns}$ & $\begin{array}{l}1.60 \\
(0.899)\end{array}$ & $\begin{array}{l}0.83 \\
(0.954 \\
)\end{array}$ & $\begin{array}{l}2.02 \\
(1.334)\end{array}$ & $\begin{array}{l}a>b * * \\
c>b * * \\
*\end{array}$ \\
\hline
\end{tabular}

886 Significance status indicated as follows *denotes significant difference at the 0.10 level, **

887 denotes significance at the 0.05 level and $* * *$ denotes significance 0.001 level, standard

888 deviation in parenthesis. $a=M A F F S, b=S L A R I, C=N G O$. Only significant differences

889 highlighted otherwise ns (not significant)/not shown. > denotes significantly greater than. 


\section{References}

Agwu, A.E., Ekwueme, J.N., and Anyanmu, A.C., 2008. Adoption of improved agricultural technologies disseminated via radio farmers programme by farmers in Enugu State, Nigeria. Nsukka, Nigeria; Department of Agricultural Extension, University of Nigeria.

Ajzen, I., 1991. The theory of planned behaviour Organizational behaviour and human decision processes 50, 179-211.

Ajzen, I., 2005. Attitudes, personality and behaviour 2nd ed. Open University Press, Maidenhead.

Ajzen, I., 2011. The theory of planned behaviour: reactions and reflections. Psychology \& health 26, 1113-1127

Ajzen, I. and Fishbein, M., 1980. Understanding attitude and predicting social behaviour. Englewood Cliffs, NJ: Prentice-Hall.

Arriagada, R.A., Sills, E. O., Pattanayak, S. K., \& Ferraro, P. J. , 2009. Combining qualitative and quantitative methods to evaluate participation in Costa Rica's program of payments for environmental services. Journal of Sustainable Forestry 28, 343-367.

Bagchee, A. (1994). Agricultural Extension in Africa. World Bank Discussion Papers. Africa Technical Department Series.Bangura, M.A.T. (2006). The Impact of the NERICA rice varieties on Farm Output and Farmers' Incomes in Sierra Leone. Rice Research Station Rokupr.

Beedell, J., Rehman, T., 2000. Using social-psychology models to understand farmers' conservation behaviour Journal of Rural Studies 16, 117-127.

Borges, J.A.R., Oude Lansink, A.G.J.M., Marques Ribeiro, C., Lutke, V., 2014. Understanding farmers' intention to adopt improved natural grassland using the theory of planned behavior. Livestock Science 169, 163-174.

Caswell, K.F., Ingram, C., Jans,S., Kascak, C., 2001. Adoption of agricultural production practices: Lessons learned from the US Department of Agriculture Area Studies Project. US Department of Agriculture, Economic Research Service.

Chambers, R., \& Jiggins, J. (1987). Agricultural Research for Resource-Poor Farmers Part 11: A Parsimonious Paradigm Agricultural Administration and Extension, 27, 109-128.

Conteh, A.S. (2003). The Effect of Clintele Participation on the Adoption of a New Rice Variety (ROK 10) in Tonko Limba Chiefdom, Kambia District. Undergraduate Thesis. Naja University College, Freetown.

Feder, G., Anderson, J. R., Birner, R. and Deininger, K, 2010. Promises and Realities of Community-Based Agricultural Extension. . IFPRI.

Fishbein, M., and Ajzen, I, 1975. Belief, attitude, intention, and behavior: An introduction to theory and research. Addison-Wesley, Reading, MA.

Francis, J., Eccles, M.P., Johnston, M., Walker, A.E., Grimshaw, J.M., Foy, R., Kner, E.F.S., Smith, L. \&Bonetti, D. (2004). Constructing questionnaires based on the theory of planned behaviour: A manual for health services researchers. Newcastle upon Tyne. 
Garforth, C., McKemey, K., Rehman, T., Tranter, R., Cooke, R., Park, J., Dorward, P., Yates, C., 2006. Farmers' attitudes towards techniques for improving oestrus detection in dairy herds in South West England. Livestock Science 103, 158-168.

Garforth, C.J., Rehman, T., McKemey, K., Tranter, R. B., Cooke, R. J., Yates, C. M., Park, J.R., Dorward, P., 2004. Improving the design of knowledge transfer strategies by understanding farmer attitudes and behaviours. Journal of Farm Management 17-32.

Gervacio, J. D. (2012). Agricultural innovation processes and innovation systems in rural Davao Region, Philippines. PhD Thesis. University of Reading. UK.

Government of Sierra Leone (GOSL) (2010). National Sustainable Agriculture Development Plan/Smallholder Commercialization Programme Investment Plan. Ministry of Agriculture, Forestry and Food Security. Freetown

Hellin, J. (2012). Agricultural Extension, collective action and innovation Systems: Lessons on network brokering from Peru and Mexico. The Journal of Agricultural Education and Extension, 18 (2) 141-159.

Klerkx, L., van Mierlo, B. \& Leeuwis, C. (2012). Evolution of Systems Approaches to Agricultural Innovation: Concepts, Analysis and Interventions. In Darnhofer, I., Gibbon, D. P. \& Dedieu, B. (eds.). Farming Systems Research Into the $21^{\text {st }}$ Century: The new Dynamic. Springer.

Läpple, D., Kelley, H., 2013. Understanding the uptake of organic farming: Accounting for heterogeneities among Irish farmers. Ecological Economics 88, 11-19.

Lalani, B., Dorward, P., Holloway, G. and Wauters, E. (2016). Smallholder farmers' motivations for using Conservation Agriculture and the roles of yield, labour and soil fertility in decision making. Agricultural systems, 146. pp. 80-90/ ISSN 0308-521X. doi:10.1016/j.agsy.2016/04/002.

Leeuwis, C. (2004). Communication for Rural Innovation: Rethinking Agricultural Extension. Blackwell Science Inc.

MAFFS., 2011. Annual Report 2011. MAFFS. Freetown.

MAFFS., 2012. Agricultural Extension Strategic Plan 2012 -2016. MAFFS. Freetown.

McKemey, K. and Sakyi-Dawson, O. (2000). Rice crop protection technology uptake blockages amongst rice farmers in Ghana: with particular reference to variety adoption and the reduction of pesticide use. Legon, Ghana: University of Ghana. Document Number.

Mango, N., Siziba, S., Makate, C. (2017). The Impact of Adoption of Conservation Agriculture on Smallholder Farmers' Food Security in Semi-Arid Zones of Southern Africa. Journal of Agriculture and Food Security. DOI 10.1186/s40066-017-0109-5.

Martínez-García, C.G., Dorward, P., Rehman, T., 2013. Factors influencing adoption of improved grassland management by small-scale dairy farmers in central Mexico and the implications for future research on smallholder adoption in developing countries. Livestock Science. 
Mgalama, P.V. (2014). The role of agricultural extension services in socio-economic development of east Africa: A critical review. Volume 44, Issue 1, pages 53-64. Tanzania Public Service College. Tanzania.

Ministry of Agriculture, Forestry and Food Security (MAFFS), (2010). Smallholder Commercialisation Programme Investment Plan. Freetown.

Ministry of Agriculture and Forestry (MAF)., 2000. Ministry of Agriculture and Forestry Annual Report. Freetown. Vol.1120 (5):56.

Ministry of Agriculture and Forestry (MAF)., 2004. Agricultural Sector Review and Agricultural Development Strategy Main Report. MAFFS. Freetown

Ministry of Agriculture, Forestry and Food Security (MAFFS)., 2010. Smallholder Commercialisation Programme Investment Plan. Freetown.

Morgan, D. L. (1998). The Focus Group Guidebook. SAGE Publications. UK

Mose, G. N. (2013). Innovation System actors' Attitudes towards the use and Effectiveness of Participatory Approaches: a case of research and extension systems in Kenya. PhD Thesis. University of Reading. UK

Moschitz, H. and Home, R., (2014). "The Challenges of Innovation for Sustainable Agriculture and Rural Development: Integrating Local Actions into European Policies with the Reflective Learning Methodology." Action Research 12 (4): 392-409. Doi: $10.1177 / 1476750314539356$.

Mulhall, A. \& Garforth, C. (2000). Equity implications of reforms in the financing and delivery of agricultural extension services. Department for International Development Project R6470 Final Technical Report March 2000.

National Population and Housing Census, 2015. The Sierra Leone National Population and Housing Census. Government of Sierra Leone. Freetown. Sierra Leone.

Patton, M.Q., 2002. Qualitative Research and Evaluation Methods. Sage, Thousand Oaks, CA. Republic of Sierra Leone. (2009). National Sustainable Agriculture Development Plan 20102030. Online -

URL:http://www.jica.go.jp/english/operations/thematic_issues/agricultural/pdf/ sierraleone_en.pdf

Robson, C. (2011). Real World Research. A Resource for Users of Social Research Methods in Applied Settings. Third Edition. John Wiley and Sons, Ltd. UK

Rogers, E. (1962). Diffusion of Innovations ( $1^{\text {st }}$ Edition). New York: Free Press.

Rogers, E. (1993). Diffusion of Innovations (3rd Edition). New York: Free Press.

Roling, N. (2006). Conceptual and Methodological Developments in Innovation. Centre for Tropical Agriculture (CIAT) - Africa.

Sierra Leone Agricultural Research Institute (SLARI), (2011). Sierra Leone Agricultural Research Institute Strategic Plan 2012 - 2021. MAFFS. Freetown. 
Swanson, B. E., Bentz, R. P., \& Sofranko, A. J. (1997). Improving agricultural extension: A reference manual. Rome, Italy: FAO. [Online] [Accessed - 15/10/14] URL: http://www.fao.org/docrep/W5830E/w5830e00.htm\#ContentS

Wauters, E., Bielders, C., Poesen, J., Govers, G., Mathijs, E., 2010. Adoption of soilconservation practices in Belgium: An examination of the theory of planned behaviour in the agri-environmental domain. Land Use Policy 27, 86-94.

West Africa Rice Company (WARC) (2013). Pioneering High-Yield Rice Production in Sierra Leone: Recommendations for an Outgrower Model. WARC. Freetown

World Bank. (2008). World Development Report, 2008. Washington, DC: The World Bank.

World Bank. (2013). A Poverty Profile of Sierra Leone. Poverty Reduction \& Economic Management Unit. Africa Region.

World Bank. (2013a). Agriculture, value added (\% of GDP). [Online - Accessed: 20/11/14]

World Food Programme. (2011). The State of Food Security and Nutrition in Sierra Leone, 1044 2011. WFP. Sierra Leone. [Online - Accessed: 20/11/14] URL:

1045 http://home.wfp.org/stellent/groups/public/documents/ena/wfp250158.pdf 